University of Wollongong

Research Online

Faculty of Engineering and Information

Faculty of Engineering and Information

Sciences - Papers: Part A

Sciences

$1-1-2017$

Stabilization of track substructure with geoinclusions- experimental evidence and DEM simulation

Ngoc Trung Ngo

University of Wollongong, trung@uow.edu.au

Buddhima Indraratna

University of Wollongong, indra@uow.edu.au

Cholachat Rujikiatkamjorn

University of Wollongong, cholacha@uow.edu.au

Follow this and additional works at: https://ro.uow.edu.au/eispapers

Part of the Engineering Commons, and the Science and Technology Studies Commons

Research Online is the open access institutional repository for the University of Wollongong. For further information contact the UOW Library: research-pubs@uow.edu.au 


\title{
Stabilization of track substructure with geoinclusions- experimental evidence and DEM simulation
}

\begin{abstract}
This article reviews on current knowledge of rail track geomechanics, including several important concepts and topics related to laboratory testing and computational modelling, to study the shear stressstrain and deformation of ballast improved by geosynthetics and recycled rubber mats. The effect that impact loads have on ballast degradation and its mitigation due to resilient synthetic mats (i.e. rubber mats) between the ballast and the subballast is investigated using large-scale impact-testing apparatus. Computational modelling with finite element and discrete element methods are increasingly being used to model ballasted tracks reinforced with geosynthetics to capture the continuum media of formation soils and the discrete nature of ballast aggregates. The article focuses on reviewing previous studies by the University of Wollongong on ballasted track substructure and highlights some practical implications whereby innovation progresses from theory to practice.
\end{abstract}

\section{Keywords}

geoinclusions, evidence, dem, experimental, simulation, stabilization, substructure, track

\section{Disciplines}

Engineering | Science and Technology Studies

\section{Publication Details}

Ngo, N., Indraratna, B. \& Rujikiatkamjorn, C. (2017). Stabilization of track substructure with geoinclusions - experimental evidence and DEM simulation. International Journal of Rail Transportation, $5(2), 63-86$. 


\title{
Stabilisation of track substructure with geo-inclusions - experimental evidence and DEM simulation
}

\author{
Ngoc Trung Ngo, PhD, MEng, BEng
}

Research fellow, Centre for Geomechanics and Railway Engineering, Faculty of Engineering and Information sciences, University of Wollongong, Wollongong City, NSW 2522, Australia; ARC Centre for Excellence for Geotechnical Science and Engineering, Australia Faculty of Engineering, Australia

\section{Buddhima Indraratna, $\mathrm{PhD}$ (Alberta), FIEAust., FTSE, FASCE}

Research Director, Distinguished Professor of Civil Engineering, Centre for Geomechanics and Railway Engineering, Faculty of Engineering and Information sciences, University of Wollongong, Wollongong, NSW 2522, Australia. ARC Centre for Excellence for Geotechnical Science and Engineering, Australia

\section{Cholachat Rujikiatkamjorn, $\mathrm{PhD}$, MEng, BEng}

Associate Professor, Centre for Geomechanics and Railway Engineering, Faculty of Engineering, University of Wollongong, Wollongong City, NSW 2522, Australia; ARC Centre for Excellence for Geotechnical Science and Engineering, Australia

Invited paper submitted to: International Journal of Rail Transportation

Author for correspondence:

Dr. Ngoc Trung Ngo

Email: trung@uow.edu.au 


\title{
Stabilisation of track substructure with geo-inclusions - experimental evidence and DEM simulation
}

\author{
Ngoc Trung Ngo ${ }^{a}$, Buddhima Indraratna ${ }^{\mathrm{b}}$ and Cholachat Rujikiatkamjorn ${ }^{\mathrm{c}}$
}

\begin{abstract}
${ }^{a}$ Research Fellow, Centre for Geomechanics and Railway Engineering, Faculty of Engineering and Information Sciences, ARC Centre of Excellence for Geotechnical Science and Engineering University of Wollongong, Wollongong, NSW 2522, Australia. Email: trung@ uow.edu.au, Ph: +61 242213385 Fax: +61242213238

${ }^{b}$ Research Director, Distinguished Professor of Civil Engineering, Centre for Geomechanics and Railway Engineering, Faculty of Engineering and Information Sciences, ARC Centre of Excellence for Geotechnical Science and Engineering, University of Wollongong, Wollongong, NSW 2522, Australia. Email: indra@uow.edu.au,Ph: +61242213046Fax: +61 242213238

${ }^{c}$ Associate Professor, Centre for Geomechanics and Railway Engineering, Faculty of Engineering and Information Sciences, ARC Centre of Excellence for Geotechnical Science and Engineering, University of Wollongong, Wollongong, NSW 2522, Australia. Email: cholacha@ uow.edu.au, Ph: +61 242215852 Fax: +61242213238
\end{abstract}

ABSTRACT: This paper reviews on current knowledge of rail track geomechanics, including several important concepts and topics related to laboratory testing and computational modelling, to study the shear stress-strain and deformation of ballast improved by geosynthetics and recycled rubber mats. The effect that impact loads have on ballast degradation and its mitigation due to resilient synthetic mats (i.e. rubber mats) between the ballast and subbballast is investigated using large-scale impact testing apparatus. Computational modelling with finite element and discrete element methods are increasingly being used to model ballasted tracks reinforced with geosynthetics to capture the continuum media of formation soils and the discrete nature of ballast aggregates. This paper focuses on reviewing previous studies by the University of Wollongong on ballasted track substructure, and highlights some practical implications whereby innovation progresses from theory to practice.

KEYWORDS: Rail transportation; ballasted tracks; geosynthetics; computational modelling 


\section{Introduction}

Ballasted rail tracks are the major infrastructure catering for public and freight transport in Australia, with a 33,400 km long network that offers an essential supply chain for agricultural and mining industries. Traditional rail track substructures are becoming overloaded due to an increasing demand for hauling heavier freight and faster trains, both of which increase the rate of track deterioration and the maintenance costs $[1,2]$. Ballast is a free-draining granular medium designed as a load-bearing layer in rail tracks; its main functions are: (i) transmitting induced train loads to the underneath layers at a reduced and acceptable level of stress, (ii) providing lateral resistance, and (iii) facilitating drainage for tracks [1, 3]. Significant degradation of ballast due to track substructures subjected to large cyclic stresses causes the ballast becomes fouled, less angular, and its shear strength decreases. These problems can be mitigated by utilising planar geosynthetics (geogrids, geotextiles, geocomposite); threedimensional cellular reinforcement (geocells) and energy absorbing rubber mats. Budiono et al. [4] state that fine particles reduce the strength and stiffness of track substructure, while Tutumluer et al. [5] report that its shear strength decreases continually as the level of fouling increases; ballast fouling leads to excessive track settlement and instability, as well as high maintenance costs $[6,7]$. There are a number of studies which highlight that ballast breakage and confining pressure are key parameters governing the behaviour of ballasted rail tracks $[8,9,10,11,12]$, which is why railway associations resist the inroads of other modes of transportation by continuously improving rail efficiency and the cost of construction and maintenance.

The cost of track maintenance can decrease if the geotechnical engineering of the ballast aggregates is assessed properly $[2,13,14]$ because inserting artificial synthetic materials into the ballast enhances the efficiency and performance of ballasted track substructures [15, 16, 17]. Reinforcing track with geogrids also helps to confine the ballast within the apertures which in turn reduces the downward propagation of stresses, reduces vertical and lateral plastic deformation, and increases the resilient long term performance of the ballast layer [18, 19]. Geocomposite such as geogrid and non-woven geotextiles simultaneously reinforce the ballast grains and provide filtration and separation functions [20, 21]. Moreover, sub-surface drainage via geosynthetic drains has also been very effective in rapidly dissipating cyclic-induced pore water pressures in the soft subgrade (e.g. clay and silts) during the passage of trains, as well as preventing soil liquefaction (mud pumping) [22]. 


\section{Applications of geosynthetics, geocells and rubber mats in ballasted tracks}

The use of planar geosynthetics to improve the performance of ballasted tracks are the subject of numerous studies carried out by Bathurst and Raymond [23]; McDowell et al.[12], Brown et al. [24]; Indraratna et al. [25], among others. Placing geosynthetics such as geogrids or non- woven geotextiles under the ballast layer confines the aggregates via interlock or frictional resistance between the ballast grains which then stiffens the surrounding particles [3,7], and increases the shearing resistance. This results in a more resilient long term performance of rail track, as well as helping with drainage and reducing ballast degradation $[17,19,26]$. The ability of geogrids to provide additional confinement to track substructures is noted by Selig and Waters [1], Indraratna et al.[10], Rujikiatkamjorn et al. [27]; their studies indicate that the interaction between ballast and geogrid is one of the governing parameters controlling the performance of geogrids in ballasted rail tracks.

\subsection{Laboratory testing}

A series of large-scale cyclic tests for fresh and coal-fouled ballast were carried out using a unique track process simulation apparatus (TPSA) designed and built at the University of Wollongong (Figure 1). This apparatus can accommodate a ballast assembly that is $800 \mathrm{~mm}$ long, $600 \mathrm{~mm}$ wide and $600 \mathrm{~mm}$ high. It is large enough to accommodate a unit cell that represents the length of a typical sleeper $(1=800$ $\mathrm{mm})$ and the distance between two adjacent sleepers $(B=600 \mathrm{~mm})$. Settlement pegs and Linear Voltage Differential Transformers (LVDTs) are installed at various locations in the TPSA to measure the vertical and horizontal deformation of ballast, while the cyclic vertical stresses are measured by pressure cells at the sleeper-ballast and ballast-subballast interfaces. Samples of ballast selected from Bombo quarry, New South Wales, Australia, are cleaned and sieved according to Australia Standard [28]. A 100mm thick layer of dry gravel and sand is compacted and used as subballast to achieve a representative field unit weight of about $18.5 \mathrm{kN} / \mathrm{m}^{3}$. A layer of geosynthetics is then placed onto the subballast (i.e. at the interface of capping (sub-ballast) and ballast layer), which is then covered with ballast and compacted to a field unit weight of $15.5 \mathrm{kN} / \mathrm{m}^{3}$. It is noted that compaction of ballast was carried out in several layers, each about $100 \mathrm{~mm}$ thick using a ballast compactor. By correlating the stiffness of support and its effect on the vibration frequency of vibratory rollers, the density of constructed ballast layers in the field can be controlled. The ballast is placed in multiple layers, each of which is compacted with a hand-held vibratory tamper to achieve the desired unit weight. The total thickness of ballast layer is $300 \mathrm{~mm}$. Fouled ballast is made by spreading a predetermined amount of coal fines into each sub-layer of ballast, 
and then an air hose is used to blow the fines through the ballast voids. This realistically mimics fines falling off wagons and infiltrating the ballast in the field. Table 1 shows the technical specifications of the geosynthetics and granular materials used in this study; the materials tested in this study are presented in Figure 2, and the particle size distribution of materials used in the laboratory are shown in Figure 3. Coal fines were used as the fouling material and the Void Contamination Index (VCI) proposed earlier by Indraratna et al. [29] was adopted used to quantify the levels of ballast fouling.

A cyclic load is applied by a servo-dynamic hydraulic actuator at a frequency of $15 \mathrm{~Hz}$ with a maximum cyclic stress of $420 \mathrm{kPa}$, to simulate an Australian train travelling at approximately $80-90 \mathrm{~km} / \mathrm{h}$. The maximum cyclic stress is determined using the American Railway Engineering Association (AREA) method. Lateral confining pressures of $7 \mathrm{kPa}$ in a transverse direction (parallel to sleeper), and $10 \mathrm{kPa}$ in a longitudinal direction (perpendicular to sleeper) are applied to simulate in-situ track conditions; this confining pressure is applied through the hydraulic jacks mounted on the sides of the apparatus. Fresh and fouled ballast is then tested at different Void Contamination Indexes, VCI $[6,30]$ up to $\mathrm{N}=500,000$ number of cycles, that is enough to capture the long term performance of ballasted tracks.

The vertical settlement of ballast is determined by excluding any deformation of the sub-ballast and subgrade. Figure 4a shows variations in the settlement (S) of fresh and fouled ballast with and without geogrid against an increased number of load cycles; for a given VCI, geogrid-reinforced fouled ballast experiences less settlement than the unreinforced assembly, possibly due to the mechanical interlock at the ballast-geogrid interface that minimises displacement. As anticipated, an increasing degree of fouling leads to increased ballast settlement, in fact ballast settles rapidly as soon as the loading cycles commence, but the rate of settlement decreases once it reaches a relatively 'stable' zone after a certain number of load cycles (i.e. 300,000 cycles). This indicates that ballast aggregates undergo considerable rearrangement and densification during the initial load cycles [2, 5]. Figure $4 \mathrm{~b}$ shows the horizontal displacement $(L)$ of fresh and fouled ballast plotted against the number of load cycles, and illustrates how the geogrid substantially reduces the lateral displacement of ballast in comparison to the unreinforced cases. Geogrid offers internal confinement which improves the lateral stability of ballast layer [2, 31]. This reinforcement action by the geogrid commences during cyclic loading and is responsible for reducing the lateral deformation of ballast [32]. Indeed, when the ballast aggregates are compacted over the geogrid, they partially penetrate and are then locked into the apertures, which then create a strong mechanical interlock between the geogrid and now restrained grains of ballast. This interlocking effect enables geogrids to act like a non-horizontal displacement boundary which confines 
and restrains the ballast from free displacement. This finding is supported by studies carried out by Tutumluer et al. [5] and McDowell et al. [12]. This result has a significant bearing on the maintenance of rail tracks due to the way geogrids curtail the deformation of ballast.

\subsection{Field study at Singleton}

To determine how well different types of geosynthetics would enhance the overall performance of ballasted tracks under in-situ conditions, an extensive study has been carried out on fully instrumented sections of track. Construction of this track began in July 2009 and commissioning took place in May 2010 by Indraratna et al. [22]. The track has several sections with different types of subgrades, including (i) relatively soft general fill and alluvial silty clay (Sections 1-5 and Section A), (ii) intermediate cut siltstone (Section C), and (iii) a stiff reinforced concrete bridge deck supported by a piled abutment (Section B), as shown in Figure 5a. The track substructure has a $300 \mathrm{~mm}$ thick layer of ballast over a $150 \mathrm{~mm}$ thick layer of subballast, and a $500 \mathrm{~mm}$ thick layer of structural fill with below the subballast. Three types of geosynthetics have been installed; (i) geogrid (aperture size A1=65 $\times 65 \mathrm{~mm}$ ), (ii) geogrid (aperture size, A2 $=44 \times 44 \mathrm{~mm}$ ), and (iii) geogrid (A3 = 40 $\times 40 \mathrm{~mm}$ ). There is also a layer of geogrid at Sections 1-3 and 5 and a layer of geocomposite (aperture size A4 = 31 $\times 31 \mathrm{~mm}$ combined with nonwoven geotextile) at Section 4. Further details of the physical characteristics and technical specifications of the geosynthetic grids are given elsewhere by Indraratna et al. [22].

Figure $5 \mathrm{~b}$ shows the vertical deformation $\left(S_{v}\right)$ of the ballast plotted against the number of load cycles $(N)$ for soft soil foundations; these results indicate that the relationship between deformation and the number of load cycles is non-linear, regardless of how the substructure has been built. The rate of increase in $S_{v}$ decreases as the number of load cycles increases. For a given section, the vertical settlements of the reinforced sections are 10-32\% smaller than those without reinforcement. This pattern is similar to that observed in the laboratory [29], and is mainly due to interlocking between the ballast grains and geogrids. When the results for sections with similar geogrids are compared, it is observed that the ability of geogrid reinforcement to reduce track settlement is generally greater for softer subgrades (low track stiffness). Previous studies has shown that the geogrid with aperture size $40 \times 40 \mathrm{~mm}$ is the optimum size because this size aperture $(40 \mathrm{~mm})$ interlocks the ballast particles best $[2,7])$. This finding also agrees with the criteria for optimum size apertures for reinforcing geogrids that the optimum geogrid aperture to maximise the interface shear strength is 1.20 times $D_{50}$. Field data from the Singleton study 
indicates that geogrid is more effective with weaker subgrade, and geogrids reduce the vertical deformation of ballast, improve track stability, and decrease the cost of maintenance.

\subsection{Applications of resilient rubber mats in rail tracks}

Planar geosynthetics placed beneath the ballast do not absorb the impact loads imparted by stiff foundations such as concrete bridge decks or level crossings [22], whereas synthetic rubber mats are an attractive option in these situations. Rubber mats have recently undergone trials on track substructure in Europe in an attempt to decrease the deformation and degradation of ballast and improve overall track stability $[34,35]$. These mats rely on their damping properties and energy absorbing capacity to isolate track structure from the relatively softer subgrade, attenuate the transmission of vibrations, and thereby reduce track deformation while having a beneficial effect on track alignment [36]. The ability of rubber mats to minimise noise along stiff tracks over concrete bridges and in tunnels, as well as controlling vibration along open tracks has been studied by Auersch [37], and Anastasopoulos et al. [38]. However, there is a limited scientific basis for their use as inclusions to absorb energy from repeated passing trains. Preliminary studies by Nimbalkar et al. [22] showed that the performance of rubber mats depends on the type of substructure (e.g., soft soil, stiff clay, and rock etc.), the loading magnitude and frequency (i.e. axle loads and train speeds), and their energy absorbing properties.

Nimbalkar et al. [33] carried out large scale drop-weight impact tests (Figure 6) to study how impact loads affect the deformation of ballast. The equipment has been designed and built at the University of Wollongong (UOW) and consists of a $5.81 \mathrm{kN}$ free fall hammer that can be dropped from a height of 6 $\mathrm{m}$ at an equivalent velocity of $10 \mathrm{~m} / \mathrm{s}$. The hammer is lifted mechanically to a designed drop height and released electronically. Ballast specimens $300 \mathrm{~mm}$ in diameter by $300 \mathrm{~mm}$ high are used in the laboratory (Figure 6b,c). Details of the material specifications and test program are described elsewhere by Nimbalkar et al. [33]. All the test assemblies are confined within a $10 \mathrm{~mm}$ thick rubber membrane to prevent piercing by sharp edges during testing. The $10 \mathrm{~mm}$ thick rubber mat used is made from 1-3 mm recycled rubber granulates bound by a polyurethane elastomer compound. A circular steel plate (thickness $t=50 \mathrm{~mm}$ ) is used to represent a stiff subgrade such as a bridge deck, and a thin layer of compacted sand is used to simulate relatively weak subgrade conditions. Weak subgrade was tested as soft sandy sand, having modulus of around $75 \mathrm{kPa}$. The stiff subgrade was used as concrete plate, having modulus of about $17 \mathrm{GPa}$. During testing, the transient impact forces are measured by a dynamic load cell (capacity of $1200 \mathrm{kN}$ ) placed on the drop-weight hammer. Piezoelectric accelerometers are 
used to record the transient accelerations, and sample deformations are recorded by electronic potentiometers after each blow.

Two distinct force peaks occur during impact loading, i.e. an instantaneous sharp peak with a very high frequency known as $P_{l}$, and a gradual peak with a smaller magnitude and slightly less frequency, known as $P_{2}$. The force $P_{2}$ lasts longer and is attributed to the mechanical resistance of the track substructure which leads to its ultimate compression [39]. Force $\mathrm{P}_{2}$ directly influences the degradation of ballast grains and is determined by its nominal maximum speed and nominal gross mass of the vehicle, as given by:

$P_{2}=P_{0}+2 \alpha V_{m} \times \sqrt{\frac{M_{u}}{M_{u}+M_{t}}} \times\left[1-\frac{C_{t} \pi}{4 \times \sqrt{K_{t}\left(M_{u}+M_{t}\right)}}\right] \times \sqrt{K_{t} M_{u}}$

where $P_{0}=$ maximum static wheel load $(\mathrm{kN}) ; M_{u}=$ vehicle unsprung mass per wheel $(\mathrm{kg})$, that is, the effective unsprung mass includes the rotational inertia of the traction motor armature and casing as well as the inertia force for vertical movement of the wheelset; $2 \alpha=$ total joint dip angle (radians), $\mathrm{V}_{\mathrm{m}}=$ maximum normal operating velocity $(\mathrm{m} / \mathrm{s}), M_{t}=$ equivalent track mass $(\mathrm{kg})$, nominally $M_{t}=133 \mathrm{~kg} ; K_{t}=$ equivalent track stiffness $(\mathrm{MN} / \mathrm{m})$, nominally $109 \mathrm{MN} / \mathrm{m}$; and $C_{t}=$ equivalent track damping $(\mathrm{kNs} / \mathrm{m})$, nominally $52 \mathrm{kNs} / \mathrm{m}$.

The response of the impact load-time subjected to the $1^{\text {st }}$ drop of the free-fall hammer is presented in Figure 7 where two distinct types of force peaks $P_{1}$ and $P_{2}$ are measured. Note that multiple $P_{1}$ type peaks followed by a distinct $P_{2}$ type peak occurs often, followed by a large increase of $P_{2}$ at the initial stages of impact loading, which then it becomes almost imperceptible. This shows that the ballast stabilises after being impacted a certain number of times to produce an almost constant $P_{2}$. The vertical and lateral deformation of the ballast is recorded after each blow, while the shear strain $\left(\varepsilon_{s}\right)$ and volumetric strain $\left(\varepsilon_{v}\right)$ of ballast with and without the inclusion of rubber mats are shown in Figure 7. Note how the inclusion of rubber mats at the top and bottom of the ballast reduces the shear and volumetric strains (i.e. in the order of 40 to 50\%) quite significantly, but this reduction is marginal with weak subgrade. Unlike planar geogrids where the apertures of the grids lock the aggregates together to provide a non-displacement boundary, a typical ballast mat will not provide the same degree of interlocking. However, the much greater energy absorption by these mats to reduce the effects of high impact loads would more than compensate for the less frictional interaction mobilised at the ballast-mat interface compared to geogrid with large apertures. 


\subsection{Applications of geocells in stabilising subballast in rail tracks}

Geocells (three dimensional structures) were originally developed by the U.S. Army Corps of Engineers to improve vehicular mobility over loose sandy subgrade. The performance of geocell mattress stabilised with different types of infill soils has been carried out by Saride et al. [40]. It is well recognized that the improved performance using geocells is mainly due to increased confinement. Railway organisations do not usually use geocells to confine ballast because it leads to problems with track maintenance by machinery. Instead, geocells can be used to reinforce subballast because the hoop stress mobilised in the geocell provides an additional confinement which arrests the lateral spreading of infill materials. The cost of track construction or maintenance can be reduced significantly if appropriate reinforcement is used to stabilise track substructures [16, 32].

Preliminary studies carried out at the University of Wollongong to investigate the improved performance of subballast using geocells indicate that improves the load carrying capacity by increasing the rigidity of in-filled subballast, which then improves track performance $[17,18]$. The large-scale TPSA (Figure 8) has also been used to investigate the improved performance of subballast using geocells. The particle size distribution of the tested subballast is within the range specified by the Australian rail industry $\left(D_{50}=3.3 \mathrm{~mm}, D_{\max }=19 \mathrm{~mm}, D_{\min }=0.075 \mathrm{~mm}, C_{u}=16.3, C_{c}=1.3, \gamma_{d}=19\right.$ $\left.\mathrm{kN} / \mathrm{m}^{3}\right)$. All the tests are carried out at various frequencies $(f=10-30 \mathrm{~Hz})$ under different confining pressures $\left(\sigma_{3}=5-30 \mathrm{kPa}\right)$, to represent trains travelling at approximately $75-285 \mathrm{~km} / \mathrm{h}$. Figure 9 shows the vertical strains of geocell-reinforced subballast plotted against the number of load cycles $(N)$ at various frequencies and confining pressures; note how the increased confinement by the geocells helps to reduce the vertical strains of subballast at any given frequency and confining pressure. During the first few thousand cycles the vertical strains (i.e. settlements) increase rapidly due to initial particle rearrangement and compression, but this rate of increase decreases in cycles beyond the unstable zone such that at a very high value of $N$ the vertical strain is almost a constant which is commonly known as 'shakedown' or stable densification.

Finite element analysis is also used to increase our understanding of subballast reinforced by geocell. Model tests are simulated in the finite element method (FEM) where the material properties are determined from the experimental data and model geometry that follows the TPSA $(800 \mathrm{~mm} \times 600 \mathrm{~mm}$ $\times 450 \mathrm{~mm}$ ), as shown in Figure 10. A layer of subballast modelled with a depth of $450 \mathrm{~mm}$ is used to represent variations in its height, as measured in the field. An elasto-plastic constitutive model (i.e. the Drucker-Prager yield criterion) with a non-associative rule is used to model the subballast, and linear, 
elastic-perfectly plastic material is used to simulate the geocell mattress. The elastic properties of the geocell strips are determined by tensile tests and then incorporated into the FEM model in ABAQUS. A hexagonal shape is used to simulate the actual geometry and shape of the geocell pockets. A cyclic load is applied in a stress controlled mode with a frequency of $f=10 \mathrm{~Hz}$, where the maximum and minimum load amplitudes are $166 \mathrm{kPa}$ and $41 \mathrm{kPa}$, respectively, under the same low confining pressures $(5 \mathrm{kPa} \leq$ $\sigma_{3} \leq 30 \mathrm{kPa}$ ) as those carried out in the laboratory.

Figures 10a-c present the deviatoric stress, vertical settlement contours in subballast, and stress contour in geocell for reinforced subballast subjected to cyclic loading (frequency of $f=10 \mathrm{~Hz}$; confining pressure of $\sigma_{3}=10 \mathrm{kPa}$ ) at a load cycle of $N=10,000$. The numerical results indicate that the subballast experiences the highest vertical deformation of about $S_{V}=2.57 \mathrm{~mm}$ under the footing surface, and this gradually decreases with depth, such that settlement at a depth of h $=200-250 \mathrm{~mm}$ is only around $S_{V}=$ $1.71 \mathrm{~mm}$. Figure $10 \mathrm{~d}$ shows a comparison between the vertical settlement of geocell-reinforced subballast obtained from the FEM simulations, and those measured experimentally under varying confining pressures $\left(\sigma_{3}=10-20 \mathrm{kPa}\right)$ under a frequency of $f=10 \mathrm{~Hz}$. Note that the settlements obtained from the FEM analysis agree well with those measured in the laboratory. Most of the deformation in reinforced subballast occurs at the early stage of loading ( $N \leq 3,000$ cycles) because settlement commences immediately during the initial number of cycles (particle rearrangement). The experimental and numerical results both confirm that the rate of settlement decreases to a controlled steady state after $N \geq 5,000$ cycles.

\section{Computational modelling for ballast aggregates}

\subsection{Angles of dilatancy and friction of ballast}

The stress-dilatancy concept $[41,42]$ can be used to model ballast degradation under triaxial monotonic loading:

$$
\frac{\sigma_{1}^{\prime}}{\sigma_{3}^{\prime}}=\left(1-\frac{d \varepsilon_{v}^{p}}{d \varepsilon_{1}^{p}}\right) \tan ^{2}\left(45+\frac{\phi_{f}^{\prime}}{2}\right)+\frac{d E_{B}}{\sigma_{3}^{\prime} d \varepsilon_{1}^{p}}\left(1+\sin \phi_{f}^{\prime}\right)
$$

where, $\phi_{f}^{\prime}$ is the effective friction angle excluding the effect of dilation and particle breakage $\left(\phi_{f}^{\prime}=44^{0}\right)$, and $d E_{B}$ is the incremental energy consumption by particle breakage per unit volume. The $d E_{B}$ can be expressed in terms of the ballast breakage index (BBI) as: 
$\left(\frac{d E_{B}}{d \varepsilon_{1}^{p}}\right)=\kappa\left[\left(\frac{d B B I}{d \varepsilon_{1}^{p}}\right)\right]$

where, $\kappa$ is the constant of proportionality $(\kappa=175.8)$. A new Ballast Breakage Index (BBI) specifically for railway ballast proposed by Indraratna et al. [2] was used to quantify the extent of degradation.

The non-associated plastic flow rule incorporating the rate of particle breakage during shearing is represented by:

$d \varepsilon_{v}^{p}=\left[1-\left(\frac{\sigma_{1}^{\prime}}{\sigma_{3}^{\prime}}\right) \tan ^{2}\left(45-\frac{\phi_{f}^{\prime}}{2}\right)+\kappa\left(\frac{d B B I}{\sigma_{3}^{\prime} d \varepsilon_{1}^{p}}\right)\left(1-\sin \phi_{f}^{\prime}\right)\right] d \varepsilon_{1}^{p}$

The mobilised dilatancy angle $\psi_{m}$ during loading/reloading phase is expressed as:

$\sin \psi_{m}=\frac{d \varepsilon_{1}^{p}+x d \varepsilon_{3}^{p}}{d \varepsilon_{1}^{p}-x d \varepsilon_{3}^{p}}=\frac{d \varepsilon_{v}^{p} / d \varepsilon_{1}^{p}}{2-d \varepsilon_{v}^{p} / d \varepsilon_{1}^{p}}$

where, $x$ is a constant ( $x=1$ for plane strain, and $x=2$ for axisymmetry). By incorporating the effect of particle breakage, $\psi_{m}$ can be expressed as [10]:

$\psi_{m}=\sin ^{-1}\left\{\frac{\left[1-\left(\frac{\sigma_{1}^{\prime}}{\sigma_{3}^{\prime}}\right)\left(\frac{1-\sin \phi_{f}^{\prime}}{1+\sin \phi_{f}^{\prime}}\right)+\kappa\left(\frac{d B B I}{d \varepsilon_{1}^{p}}\right)\left(\frac{1}{\sigma_{3}^{\prime}}\right)\left(1-\sin \phi_{f}^{\prime}\right)\right]}{\left[1+\left(\frac{\sigma_{1}^{\prime}}{\sigma_{3}^{\prime}}\right)\left(\frac{1-\sin \phi_{f}^{\prime}}{1+\sin \phi_{f}^{\prime}}\right)-\kappa\left(\frac{d B B I}{d \varepsilon_{1}^{p}}\right)\left(\frac{1}{\sigma_{3}^{\prime}}\right)\left(1-\sin \phi_{f}^{\prime}\right)\right]}\right\}$

The ballast deformation during cyclic loading can be determined by incremental axial strains $[2,10]$ :

$\frac{d \varepsilon_{1}^{p}}{d N}=\varepsilon_{11}^{p}\left(\frac{a^{\prime}}{N}+\frac{b^{\prime}}{N}\right)$

where, $\varepsilon_{11}^{p}$ represents vertical plastic strain after the first loading cycle, and $a^{\prime}$ and $b^{\prime}$ are two empirical

constants. For axi-symmetric $\left(\sigma_{2}^{\prime}=\sigma_{3}^{\prime} ; d \varepsilon_{2}^{p}=d \varepsilon_{3}^{p}\right)$ and plane strain $\left(d \varepsilon_{2}^{p}=0\right)$ testing conditions, incremental volumetric strain under cyclic loading is expressed as [10]:

$\frac{d \varepsilon_{v}^{p}}{d N}=\left[\left(\varepsilon_{11}^{p}\left(\frac{a^{\prime}}{N}+\frac{b^{\prime}}{N}\right)\right)-\left(\frac{\sigma_{1}^{\prime}}{\sigma_{3}^{\prime}}\right)\left(\frac{1-\sin \phi_{f}^{\prime}}{1+\sin \phi_{f}^{\prime}}\right)\left(\varepsilon_{11}^{p}\left(\frac{a^{\prime}}{N}+\frac{b^{\prime}}{N}\right)\right)+\kappa\left(\frac{d B B I}{d N}\right)\left(\frac{1}{\sigma_{3}^{\prime}}\right)\left(1-\sin \phi_{f}^{\prime}\right)\right]$ 
The values of $d \varepsilon_{v}^{p} / d \varepsilon_{1}^{p}$ can be computed from Equation (8) for a corresponding friction mobilisation, progressive breakage, and evolution of the stress state during loading or reloading. These Equations provide fundamental mathematical frameworks in determining friction coefficient of ballast, considering particle breakage. It is then used in the process of parametric study to determine appropriate input parameters for DEM model presented in the following sections.

\subsection{Discrete element modelling for ballasted tracks}

The discrete element method (DEM) introduced by Cundall and Strack [43] has been used extensively to study the behaviour of granular materials. DEM is often used to model ballast because it captures the discrete nature of a granular assembly which consists of a collection of arbitrarily shaped discrete particles subjected to quasi-static and dynamic conditions [44, 45]. Particle motion is determined using Newton's second law and the interaction between particles is determined using Newton's second law contact laws. At a given time, the force vector $\vec{F}$ that represents the interaction between the two particles (Figure 2) is resolved into normal $\left(\vec{F}_{N}\right)$ and shear component $\left(\vec{F}_{T}\right)$ with respect to the contact plane:

$\vec{F}_{N}=K_{N} U^{n}$

$\delta \vec{F}_{T}=-K_{T} \cdot \delta U^{S}$

where, $K_{N}$ and $K_{T}$ are the normal and tangential stiffnesses at the contact; $U^{n}$ is the normal penetration between two particles; $\delta U^{S}$ is the incremental tangential displacement; and $\delta \vec{F}_{T}$ is the incremental tangential force. The rolling resistance moment $\vec{M}_{r}$ is introduced to represent the rolling restraint between the two particles A and B and is determined by:

$\vec{M}_{r}= \begin{cases}K_{r} \vec{\omega}_{r} & \text { if } K_{r}\left\|\vec{\omega}_{r}\right\|<\left\|\vec{M}_{r}\right\|_{l i m} \\ \left\|\vec{M}_{r}\right\|_{l i m} \frac{\vec{\omega}_{r}}{\left\|\vec{\omega}_{r}\right\|} & \text { if } \quad K_{r}\left\|\vec{\omega}_{r}\right\| \geq\left\|\vec{M}_{r}\right\|_{l i m}\end{cases}$

where, $\left\|\vec{M}_{r}\right\|_{l i m}=\eta_{r}\left\|\vec{F}_{r}\right\| \frac{R_{A}+R_{B}}{2} \quad ; K_{r}=\gamma_{r}\left(\frac{R_{A}+R_{B}}{2}\right)^{2} ; \quad \vec{\omega}_{r}$ is a rolling angular vector representing the relative orientation change between two particles and is computed by adding the angular vectors of the incremental rolling; $\eta_{\mathrm{r}}$ is the dimensionless coefficient; and $\gamma_{\mathrm{r}}$ is the rolling resistance coefficient. 
The new shear contact force is determined by summing the old shear force existing at the start of the time-step with the shear elastic force increment

$\vec{F}_{T} \leftarrow \vec{F}_{T}+\delta \vec{F}_{T} \leq \mu \vec{F}_{N}$

where, $\mu$ is the coefficient of friction.

\subsection{Modelling laboratory tests for ballast in DEM}

Figure 11 shows how DEM is used to model geogrid-reinforced ballast in a direct shear test and track process simulation apparatus (TPSA). The model dimensions are the same as those carried out in the laboratory. Ballast grains with different shapes and sizes are modelled by clumping many spheres together to represent actual ballast gradation (Figure 11a). This method is widely used to simulate ballast aggregates, which are then placed at random locations within the specified wall boundary and without overlapping. The micromechanical parameters used to model ballast, geogrid and coal fines are adopted from Indraratna et al. [44], Ngo et al. [7] as given in Table 2. Figures $11 \mathrm{~b}$-c are describing a geogrid and a direct shear box modelled in DEM. The geogrid was secured in the middle of shear box (between the lower and upper boxes).

DEM simulations of direct shear tests are implemented at three normal stresses of $\sigma_{n}=27 \mathrm{kPa}, 51 \mathrm{kPa}$, and $75 \mathrm{kPa}$ for fresh and fouled ballast $(\mathrm{VCI}=40 \%)$ with and without the inclusison of geogrid. Figure 12 presents comparisons of shear stress-displacement responses of geogrid-reinforced ballast from the DEM analysis and those measured in the laboratory. Note that the predicted results match reasonably well with the laboratory data for a given normal stress and level of fouling. The strain softening behaviour of ballast and volumetric dilation is observed in all the simulations and show that the higher the normal stress $\left(\sigma_{n}\right)$, the greater the shear strength and the smaller the dilation. The ability of geogrid reinforcement to increase the shear strength of fresh and fouled ballast can be seen by comparing it with an assembly with unreinforced ballast.

DEM simulations of the TPSA in a plane strain condition are shown in Figure 11d. The realistic shape and size of ballast grains and the procedures for simulating them in two dimensions are adopted from Indraratna et al. [46]. Clusters of bonded circular particles are used to model irregularly shaped grains of ballast, so the breakage of bonds is considered to represent particle breakage. Cyclic tests for fresh and fouled ballast at $V C I=10 \%, 20 \%, 40 \%$ and $70 \%$ are then simulated to a number of load cycles where $N=4000$. The loading charasterictics and boundary conditions exerted onto the TPSA are identical to 
those carried out in the laboraty [29]. All ballast samples had a thickness of $300 \mathrm{~mm}$ and there is no geogrid simulated in DEM simulations of the TPSA in a plane strain condition. The cross section in Figure 11d shows the DEM simulation of the TPSA in a plane strain condition. During loading, movement of the top and surrounding walls is measured to compute the axial and associated lateral displacements. Figure 13 shows a comparison between the predicted and measured lateral displacement, settlement, and the number of broken bonds with an increase in the load cycles. Here the DEM simulations capture the load-deformation behaviour of fresh and fouled ballast reasonably well. An increase in the level of fouling (i.e. increased $V C I$ ) results in an increased lateral displacement of ballast and a subsequent increase in settlement. The DEM analysis also shows that the accumulation of broken bonds decreases as the VCI increases (Figure 13c). This observation can be justified because fine particles that clog the voids of large aggregates could help to transfer the contact forces more uniformly through the ballast skeletons; in fact the contact forces that are transferred from the ballast grains and through the fine particles in the fouled ballast matrix mimic the "cushioning effect" of fines that effectively reduce the inter-particle contact stresses, and which in turn reduce particle breakage.

Load transfer in a ballast assembly depends on the contact force distributions developed across the aggregates through an interconnected network of force chains at contact points [43, 45]. Under a shearing load these contact forces develop and evolve so that the number of load-carrying contacts and their orientations inevitably vary to carry induced stresses. Figure 14 shows the distributions of contact force chains of fresh and fouled ballast $(V C I=40 \%)$ with and without geogrid reinforcement under a given normal stress of $51 \mathrm{kPa}$, at a shear displacement of $\Delta h=18 \mathrm{~mm}$. The contact forces between the aggregates are shown as lines whose thickness is proportional to the magnitude of the force. Note how fouled ballast has denser contact chains and less maximum force than those in the fresh ballast assembly. This can be attributed to fine particles clogging the pore spaces between the large grains and the partially supported and transmitted forces across the assembly; this is believed to be due to the interlocking effect that occurs between the ballast grains and geogrid.

\section{Conclusions}

This paper encapsulates the extent of our knowledge of rail track geomechanics resulting from tests and studies carried out at the University of Wollongong over the last two decades. The use of geosynthetics (geogrids, geocoposites, geocells) and rubber mats to enhance the performance of rail tracks has been 
discussed, and we have included several important concepts/topics related to large-scale laboratory testing, field measurements, and approaches to computational modelling. A series of large-scale laboratory tests using a direct shear box, track process simulation apparatus (TPSA) and impact testing apparatus has also been carried out to study the role played by geosynthetics, geocells, and rubber mats in relation to the stress-strain and degradation response of ballast under cyclic and impact loads. Experimental data shows that geogrid increases the shear strength of ballast and decreases dilation due to interlocking between the ballast and geogrid, but fouling materials that accumulate in the ballast assemblies reduces the benefits gained from using geogrid as reinforcement because they fill the voids between the ballast particles and reduce inter-particle friction at the interface. Coal dust fouling was considered primarily as the ballast fouling case in many of the findings presented in this paper. Dynamic impact testing indicates that impact loads cause most of the damage to ballast, and substantial reduction in shear strains and particle breakage can be gained by using rubber mats. The specimens of subballast reinforced with geocell experienced much less deformation than the unreinforced cases because the confinement provided by geocell prevented the free displacement of in-fill aggregates.

DEM simulations for large-scale direct shear tests and TPSA were carried out for fresh and fouled ballast $(V C I=40 \%)$ to examine how geogrids improve the performance of ballast. The shear stress-strain behaviour obtained from the DEM analysis matched reasonably well with the measured data; in fact the DEM analysis showed that while the numbers of contacts increase significantly as the degree of fouling increases, the magnitude of the contact force also decreases considerably. That is thought to be due to the cushioning effect of fine grains lubricating ballast surfaces and reducing the particle contact forces, which in turns reduces particle degradation. The findings of these studies provide a better understanding of crucial aspects such as the ballast-geogrid interface mechanism, long-term deformation and degradation, as well as the benefits of using geosynthetics, geocells, and rubber mats to improve the performance of ballasted tracks

\section{Acknowledgements}

The Authors would like to thank the Rail Manufacturing CRC, Australasian Centre for Rail Innovation (ACRI) Limited, and Tyre Stewardship Australia Limited for providing the financial support needed to undertake this research (Project R2.5.1). The Authors are grateful Mr. Alan Grant, Mr. Cameron Neilson, Mr. Duncan Best and Mr. Ritchie McLean for their assistance in the laboratory. Laboratory and field works conducted by Dr. Biabani and Dr. Nimbalkar are greatly appreciated. Some of the 
research outcomes reported in this paper are elaborated on in the Journal of Geotechnical \& Geoenvironmental Engineering - ASCE, International Journal of Geomechanics ASCE, Computers and Geotechnics, Geotextiles and Geomembranes. The selected contents are reproduced with kind permission.

\section{References}

[1]. Selig, ET, Waters, JM. Track geotechnology and substructure management. Thomas Telford, London; 1994.

[2]. Indraratna, B., Salim, W. Rujikiatkamjorn, C. (2011). "Advanced Rail Geotechnology Ballasted Track", CRC Press, Taylor \& Francis Group, London, UK

[3]. Indraratna, B, Ngo, NT, Rujikiatkamjorn, C. Behavior of geogrid-reinforced ballast under various levels of fouling. Geotextiles and Geomembranes.2011; 29(3), : 313-322.

[4]. Budiono, DS, McSweeney, T, Dhanasekar, M, Gurung, N. The effect of coal dust fouling on the cyclic behavior of railtrack ballast. Cyclic Behavior of Soils and Liquefaction phenomena, Taylor \& Francis Group, London. 2004: 627-632.

[5]. Tutumluer, E, Dombrow, W, Huang, H. Laboratory characterization of coal dust fouled ballast behaviour. AREMA 2008 Annual Conference \& Exposition, Salt Lake City, UT, USA; 2008.

[6]. Tennakoon, N, Indraratna, B, Rujikiatkamjorn, C, Nimbalkar, S, Neville, T. The role of ballastfouling characteristics on the drainage capacity of rail substructure. Geotechnical Testing Journal; 201235(4): 1-11.

[7]. Ngo, NT, Indraratna, B, Rujikiatkamjorn, C. DEM simulation of the behaviour of geogrid stabilised ballast fouled with coal. Computers and Geotechnics; 201455 : 224-231.

[8]. Ngo, NT, Indraratna, B, Rujikiatkamjorn, C. Modelling geogrid-reinforced railway ballast using the discrete element method. Transportation Geotechnics; 2016, 8(2016): 86-102.

[9]. Lackenby, J, Indraratna, B, McDowell, GR, Christie, D. Effect of confining pressure on ballast degradation and deformation under cyclic triaxial loading. Geotechnique; 2007 57(6): 527-536.

[10]. Indraratna, B, Nimbalkar, S, Ngo, NT, Neville, T. Performance improvement of rail track substructure using artificial inclusions - Experimental and numerical studies. Transportation Geotechnics; 2016, 8:69-85.

[11]. Indraratna, B, Ngo, NT, Rujikiatkamjorn, C. Deformation of coal fouled ballast stabilized with geogrid under cyclic load. Journal of Geotechnical and Geoenvironmental Engineering, 2013, 139(8): 1275-1289.

[12]. McDowell, GR, Harireche, O, Konietzky, H, Brown, SF, Thom, NH. Discrete element modelling of geogrid-reinforced aggregates. Proceedings of the ICE - Geotechnical Engineering; 2006, 159(1): 35-48. 
[13]. Powrie, W, Yang, LA, Clayton, CRI. Stress changes in the ground below ballasted railway track during train passage. Proceedings of the Institution of Mechanical Engineers: Part F: Journal of Rail and Rapid Transit; 2007, 247-261.

[14]. LePen, L. Track behaviour: the importance of the sleeper to ballast interface. PhD Thesis, University of Southamton, UK; 2008.

[15]. Ni, Q, Powrie, W, Zhang, X, Harkness, R. Effect of particle properties on soil behaviour: 3-D numerical modelling of shearbox test. Geotechnical Special Publication, ASCE; 2000, 96: 5870.

[16]. Ngo, NT, Indraratna, B, Rujikiatkamjorn, C Biabani, MM. Experimental and discrete element modeling of geocell-stabilized subballast subjected to cyclic loading. Journal of Geotechnical and Geoenvironmental Engineering; 2016, 142(4): 04015100.

[17]. Biabani, M, Indraratna, B Ngo, NT. Modelling of geocell-reinforced subballast subjected to cyclic loading. Geotextiles and Geomembranes; 2016, 44 (4): 489-503.

[18]. Indraratna, B, Biabani, MM, Nimbalkar, S Behavior of geocell-reinforced subballast subjected to cyclic loading in plane-strain condition. Journal of Geotechnical and Geoenvironmental Engineering; 2014 141(1): 04014081.

[19]. Bathurst, RJ, Nernheim, A, Walters, DL, Allen, TM, Burgess, P, Saunders, DD. Influence of reinforcement stiffness and compaction on the performance of four geosynthetic-reinforced soil walls. Geosynthetics International; 2009, 16(1): 43-59.

[20]. Kwon, J, Penman, J. The use of biaxial geogrids for enhancing the performance of sub-ballast and ballast layers-previous experience and research. Bearing Capacity of Road, Railways and Airfields, Taylor \& Francis Group, London; 2009.

[21]. Bergado, DT, Chai, JC, Miura, N. Finite element analysis of grid reinforced embankment system on soft Bangkok clay. Computers and Geotechnics; 1995 17(4): 447-471.

[22]. Indraratna, B, Nimbalkar, S, Neville, T. Performance assessment of reinforced ballasted rail track. Proceedings of the ICE: Ground Improvement; 2014, 167 (1), 24-34.

[23]. Bathurst, RJ, Raymond, GP. Geogrid reinforcement of ballasted track. Transportation Research Record; 1987, 1153: 8-14.

[24]. Brown, SF, Kwan, J, Thom, NH. Identifying the key parameters that influence geogrid reinforcement of railway ballast. Geotextiles and Geomembranes; 2007 25(6): 326-335.

[25]. Indraratna, B, Ngo, NT, Rujikiatkamjorn, C, Vinod, J. Behaviour of fresh and fouled railway ballast subjected to direct shear testing - a discrete element simulation. International Journal of Geomechanics 2014, 14(1): 34-44.

[26]. Han, J, Bhandari, A, Wang, F. DEM analysis of stresses and deformations of geogridreinforced embankments over piles. International Journal of geomechanics; 2011, 12(4): 340350.

[27]. Rujikiatkamjorn, C, Indraratna, B, Ngo, NT, Coop, M. A laboratory study of railway ballast behaviour under various fouling degree'. Proc., Geosynthetics Asia 2012: 5th Asian Regional Conference on Geosynthetics, Thailand, 2012: 507-514..

[28]. Australian Standard: AS2758.7. Aggregates and rock for engineering purposes; Part 7 : Railway ballast. Sydney, NSW, Australia; 1996. 
[29]. Indraratna, B, Nimbalkar, S, Tennakoon, N. The behaviour of ballasted track foundations: Track drainage and geosynthetic reinforcement. GeoFlorida 2010: Advances in Analysis, Modeling \& Design (GSP 199). Fratta, D., Puppala, A. and Muhunthan, B. (Eds.); 2010, 23782387.

[30]. Ngo, NT, Indraratna, B, Rujikiatkamjorn, C. Micromechanics-based investigation of fouled ballast using large-scale triaxial tests and discrete element modeling." J. Geotech. Geoenviron. Eng. 04016089. doi: 10.1061/(ASCE)GT.1943-5606.0001587.

[31]. Ngo, NT, Indraratna, B, Rujikiatkamjorn, C. A study of the behaviour of fresh and coal fouled ballast reinforced by geogrid using the discrete element method. In K. Soga, K. Kumar, G. Biscontin \& M. Kuo (Eds.), Geomechanics from Micro to Macro, United Kingdom: Taylor \& Francis; 2015: 559-563.

[32]. Biabani, MM, Ngo, NT, Indraratna, B. Performance evaluation of railway subballast stabilised with geocell based on pull-out testing. Geotextiles and Geomembranes; 2016 44(4): 579-591.

[33]. Nimbalkar, S, Indraratna, B, Dash, SK. Christie, D. Improved performance of railway ballast under impact loads using shock mats. Journal of Geotechnical and Geoenvironmental Engineering; 2012, 138(3): 281-294.

[34]. Ferreira, PA, López-Pita, A. Numerical modeling of high-speed train/track system to assess track vibrations and settlement prediction. Journal of Transportation Engineering; 2013, 139(3): 330-337.

[35]. Costa, PA, Calçada, R, Cardoso, AS. Ballast mats for the reduction of railway traffic vibrations-Numerical study. Soil Dynamics and Earthquake Engineering; 2012, 42(0): 137-150.

[36]. Lakuši, S, Ahac, M, Haladin, I. Experimental investigation of railway track with under sleeper pad. Proceedings of the $10^{\text {th }}$ Slovenian Road and Transportation Congress; 2010: 386-393.

[37]. Auersch, L. Dynamic axle loads on tracks with and without ballast mats: numerical results of three-dimensional vehicle-track-soil models. Proceedings of the Institution of Mechanical Engineers, Part F: Journal of Rail and Rapid Transit; 2006, 220(2):169-183.

[38]. Anastasopoulos, I, Alfi, S, Gazetas, G, Bruni, S, Leuven, AV. Numerical and experimental assessment of advanced concepts to reduce noise and vibration on urban railway turnouts. Journal of Transportation Engineering, ASCE; 2009, 135(5): 279-287.

[39]. Frederick, CO, Round, DJ. Vertical track loading, Track Technology, Thomas Telford Ltd, London; 1985.

[40]. Saride, S, Puppala, AJ, Sitharam, TG, Gowrisetti, S. Numerical simulation of geocellreinforced sand and clay. Proceedings of the Institution of Civil Engineers. Ground improvement; 2009, 162(4): 185-198.

[41]. Ueng TS, Chen TJ. Energy aspects of particle breakage in drained shear of sands. Geotechnique; 2000, 50(1): 65-72.

[42]. Rowe PW. The stress-dilatancy relation for the static equilibrium of an assembly of particles in contact. Proc. Royal Society; 1962, A269: 500-527.

[43]. Cundall, PA, Strack, ODL. A discrete numerical model for granular assemblies. Geotechnique; 1979, 29(1): 47-65.

[44]. Ngo, NT, Indraratna, B, Rujikiatkamjorn, C. DEM simulation of the behaviour of geogrid stabilised ballast fouled with coal. Computers and Geotechnics; 2014, 55: 224-231. 
[45]. O'Sullivan, C. Particulate discrete element modelling: A geomechanics perspective, Taylor \& Francis; 2011.

[46]. Indraratna, B, Thakur, PK, Vinod, JS. Experimental and numerical study of railway ballast behaviour under cyclic loading'. International Journal of Geomechanics, ASCE; 2010 10(4):136-14. 
Table 1. Properties of geosynthetics and granular materials used in this study

\begin{tabular}{|c|c|c|c|c|c|c|c|}
\hline Material & & & & Propertie & & & \\
\hline Geosynthetics & $\begin{array}{c}\text { Nominal } \\
\text { Area } \\
\left(\mathrm{mm}^{2}\right)\end{array}$ & $\begin{array}{l}\text { Density } \\
\left(\mathrm{g} / \mathrm{cm}^{3}\right)\end{array}$ & $\begin{array}{c}\text { Cell } \\
\text { depth } \\
(\mathrm{mm})\end{array}$ & $\begin{array}{l}\text { Thickness } \\
(\mathrm{mm})\end{array}$ & $\begin{array}{l}\text { Aperture size } \\
(\mathrm{mm})\end{array}$ & \multicolumn{2}{|c|}{$\begin{array}{c}\text { Tensile strength } \\
\text { (kN.m) }\end{array}$} \\
\hline Geocell & $46 \times 10^{3}$ & 0.95 & 150 & 1.3 & $320 \times 287$ & \multicolumn{2}{|c|}{$\begin{array}{c}9.5 \text { (Bulk) } \\
8 \text { (Seam) }\end{array}$} \\
\hline Geogrid & - & - & - & - & $40 \times 40$ & \multicolumn{2}{|l|}{10.5} \\
\hline Granular layers & $\begin{array}{c}D_{\min } \\
(\mathrm{mm})\end{array}$ & $\begin{array}{l}D_{\max } \\
(\mathrm{mm})\end{array}$ & $\begin{array}{c}D_{50} \\
(\mathrm{~mm})\end{array}$ & $\begin{array}{c}D_{10} \\
(\mathrm{~mm})\end{array}$ & $\begin{array}{l}\text { Uniformity } \\
\text { Coefficient } \\
\qquad C_{u}\end{array}$ & $\begin{array}{c}\text { Coeff. of } \\
\text { Curvature } \\
C_{c}\end{array}$ & $G_{s}$ \\
\hline Ballast & 19 & 63 & 32 & 21 & 1.6 & 1 & 2.7 \\
\hline Sub-ballast & 0.075 & 19 & 3.3 & 0.3 & 16.3 & 1.3 & 2.7 \\
\hline
\end{tabular}


Table 2. Micromechanical parameters of geogrid, ballast and coal fines adopted for DEM simulation

\begin{tabular}{llll}
\hline Parameter & Geogrid & Ballast & $\begin{array}{c}\text { Coal } \\
\text { fines }\end{array}$ \\
\hline Particle density $\left(\mathrm{kg} / \mathrm{m}^{3)}\right.$ & & & 800 \\
Coefficient of friction & 0.5 & 0.8 & 0.2 \\
Contact normal stiffness, $k_{n}(\mathrm{~N} / \mathrm{m})$ & $1.77 \times 10^{7}$ & $0.52 \times 10^{8}$ & $1.27 \times 10^{4}$ \\
Contact shear stiffness, $k_{s}(\mathrm{~N} / \mathrm{m})$ & $0.88 \times 10^{7}$ & $0.52 \times 10^{8}$ & $1.27 \times 10^{4}$ \\
Contact normal stiffness of wall-particle, $k_{n-\text { wall }}(\mathrm{N} / \mathrm{m})$ & $1 \times 10^{8}$ & $1 \times 10^{8}$ & $1 \times 10^{8}$ \\
Shear stiffness of wall of wall-particle, $k_{s-\text { wall }}(\mathrm{N} / \mathrm{m})$ & $1 \times 10^{8}$ & $1 \times 10^{8}$ & $1 \times 10^{8}$ \\
Parallel bond radius multiplier, $r_{p}$ & 0.5 & & \\
Parallel bond normal stiffness, $k_{n p}(\mathrm{kPa} / \mathrm{m})$ & $5.68 \times 10^{8}$ & & \\
Parallel bond shears tiffness, $k_{s p}(\mathrm{kPa} / \mathrm{m})$ & $5.68 \times 10^{8}$ & & \\
Parallel bond normal strength, $\sigma_{n p}(\mathrm{MPa})$ & 456 & & \\
Parallel bond shear strength, $\sigma_{s p}(\mathrm{MPa})$ & 456 & & \\
\hline
\end{tabular}




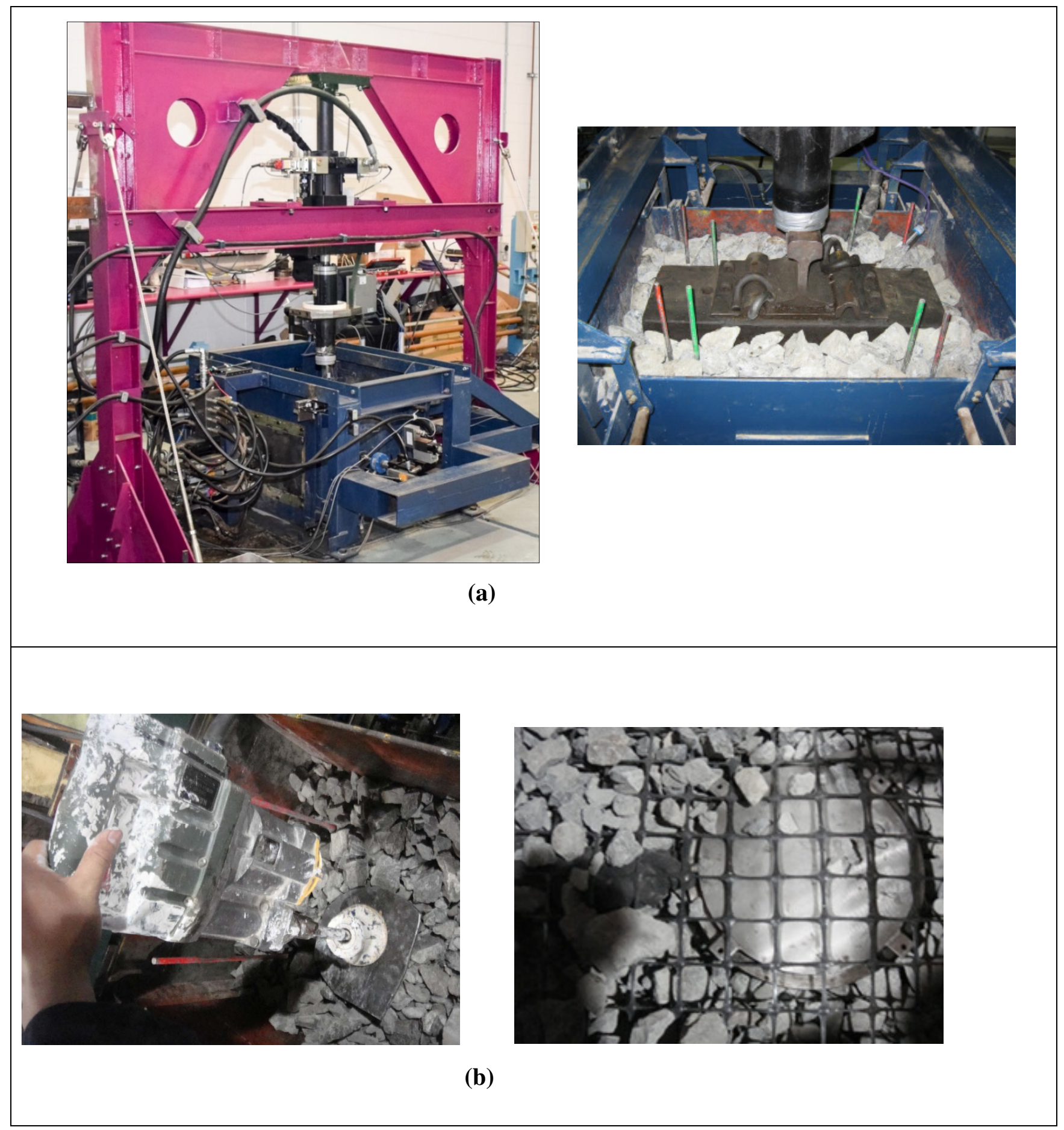

Figure 1. Large-scale laboratory tesing apparatus: (a) Track Process Simulation Apparatus (TPSA); (b) sample preparation 


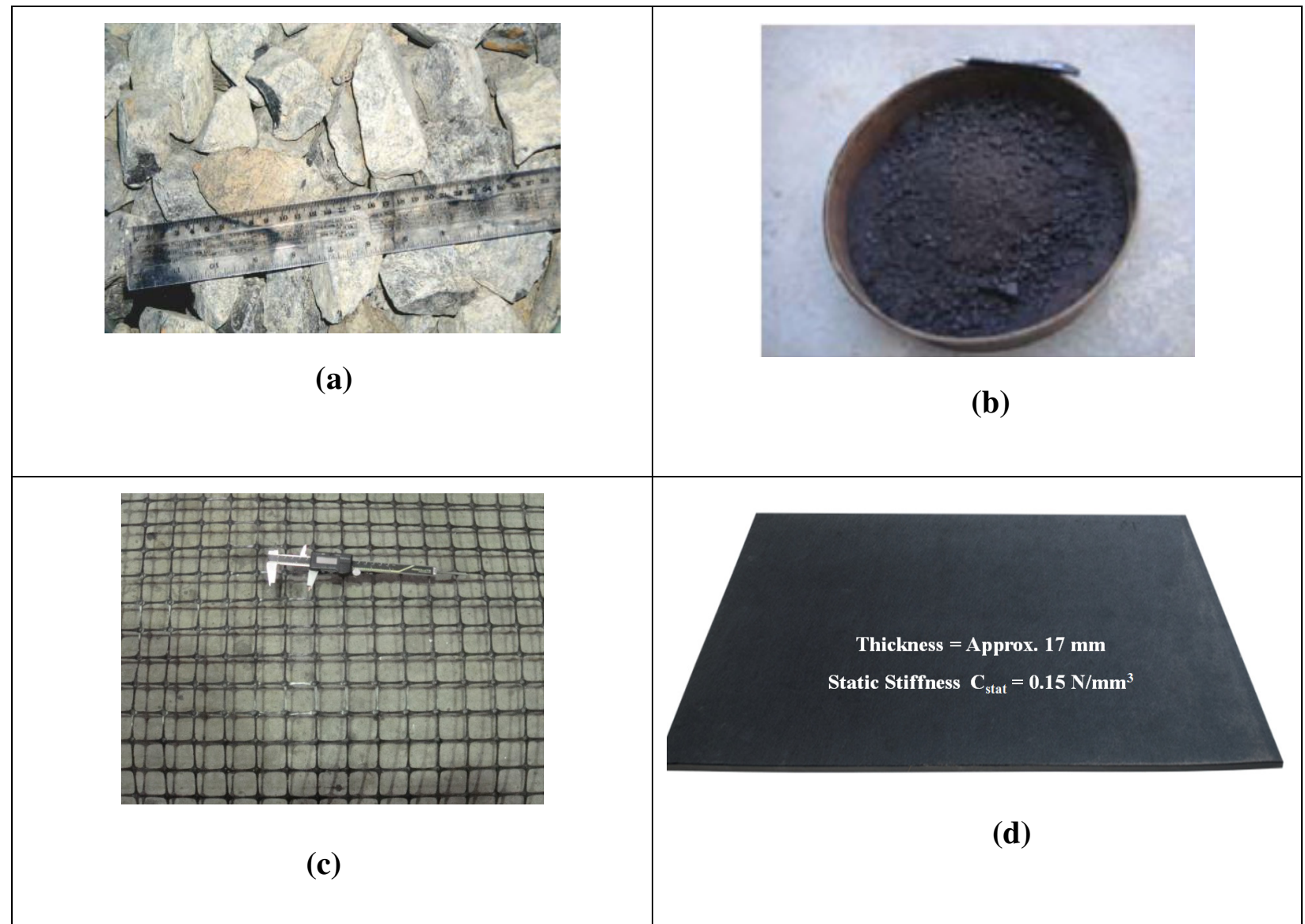

Figure 2. Materials tested in laboratory : (a) fresh ballast; (b) coal fines; (c) biaxial geogrid, 40 x 40 $\mathrm{mm}$; and (c) rubber mat 


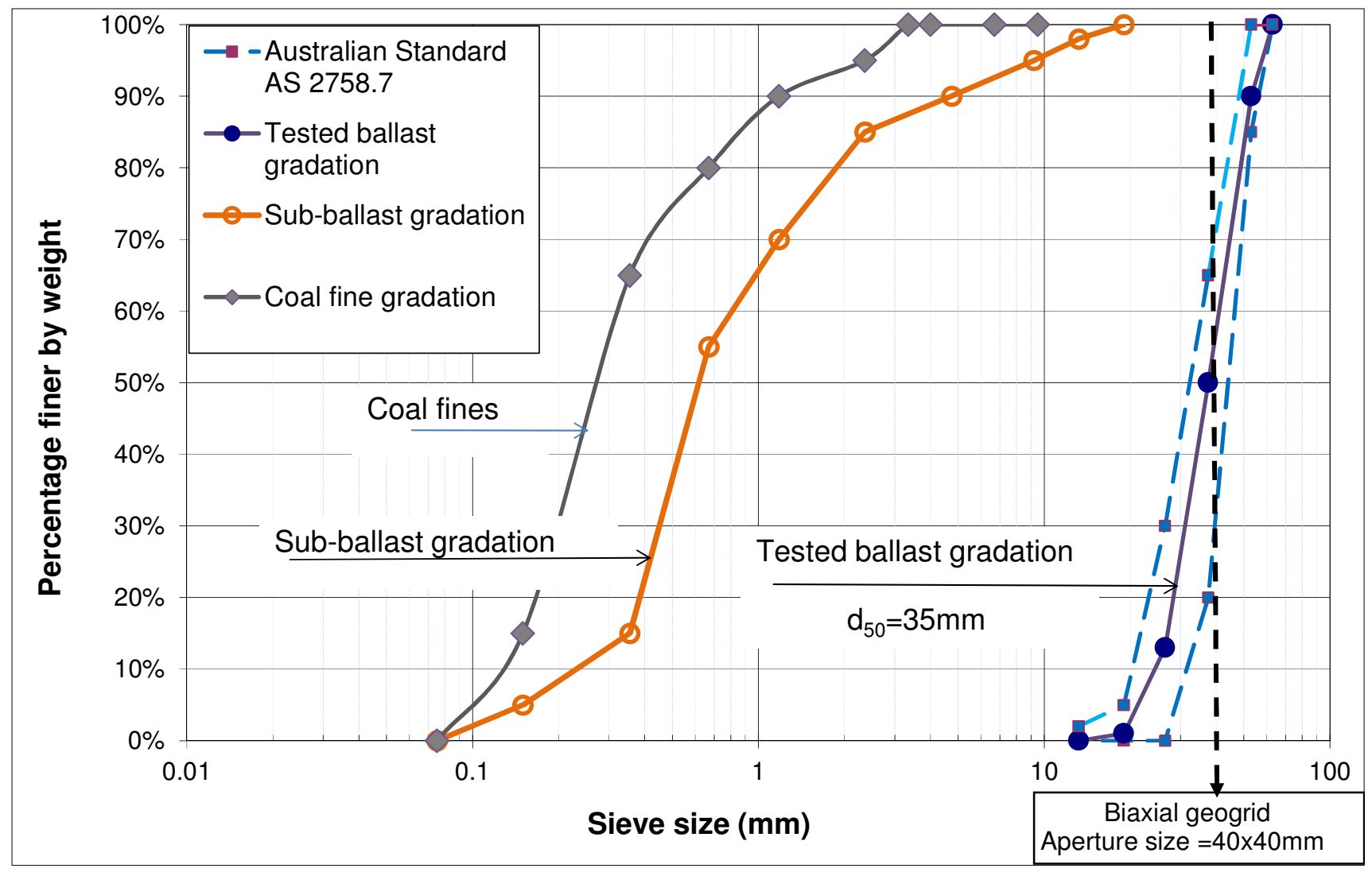

Figure 3. Gradations of materials tested in laboratory 


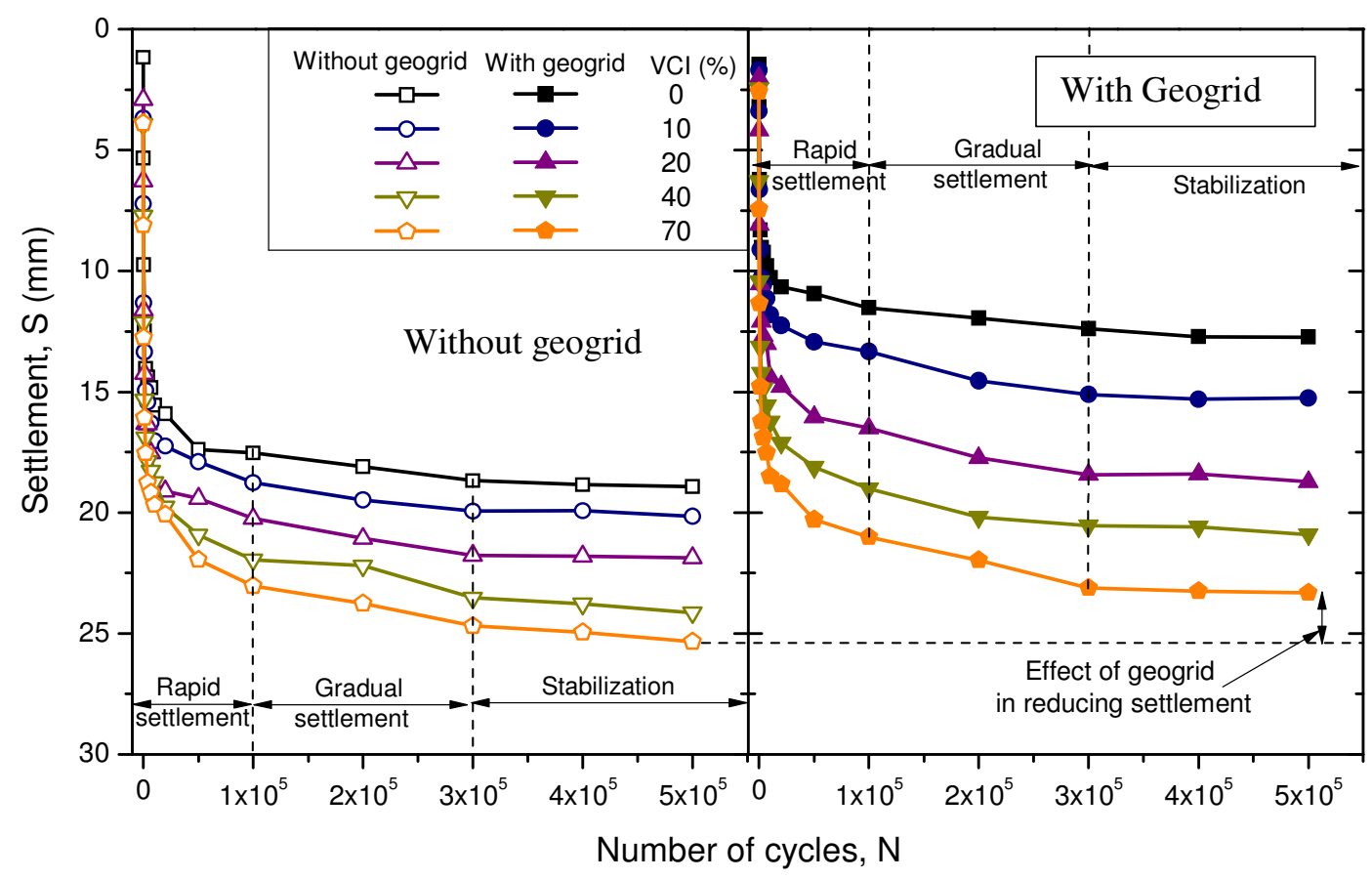

(a)

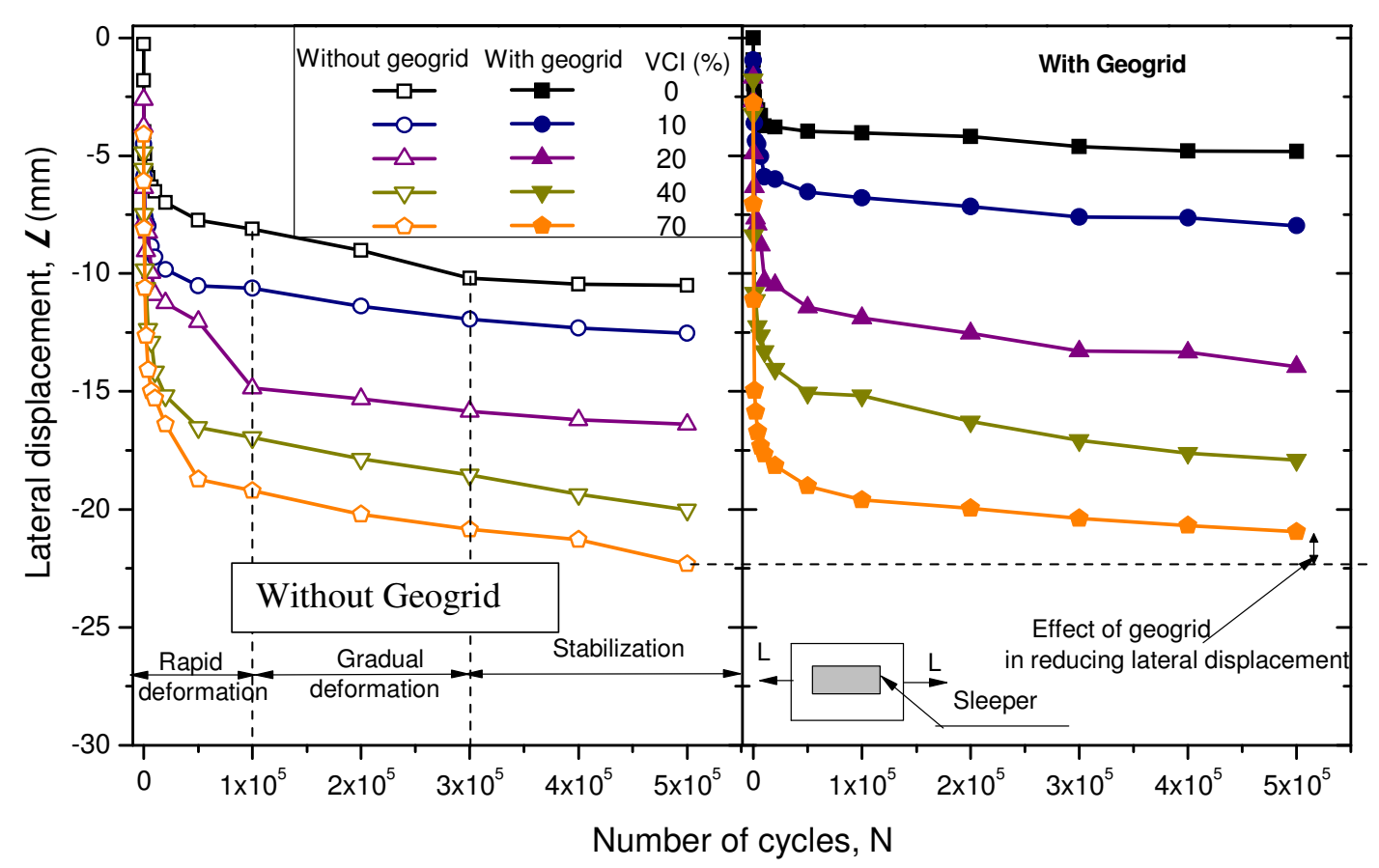

(b)

Figure 4. Variation of (a) settlements, $S$ and (b) lateral displacement, $L$ of fresh and fouled ballast assemblies with and without geogrid inclusions 


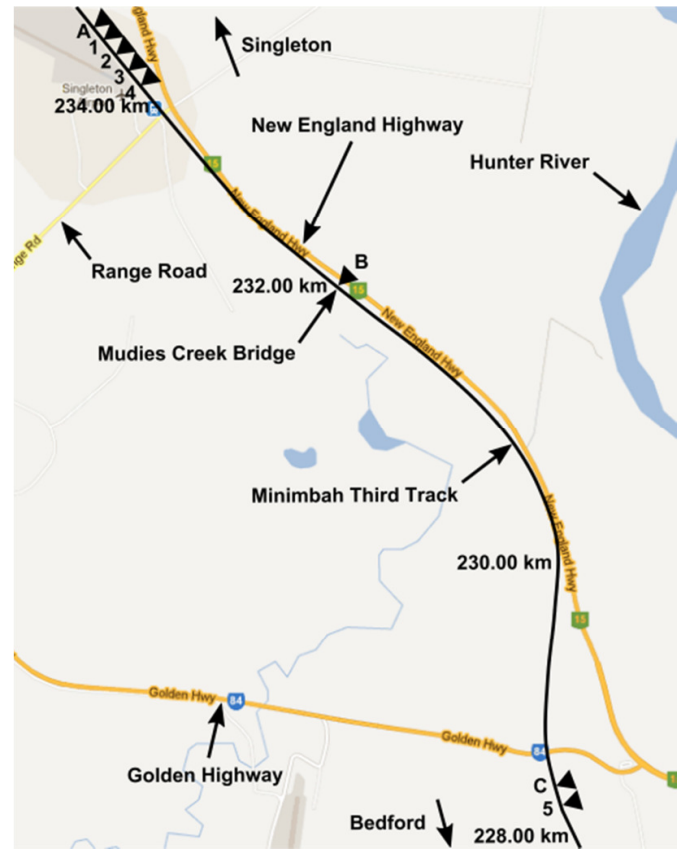

(a)

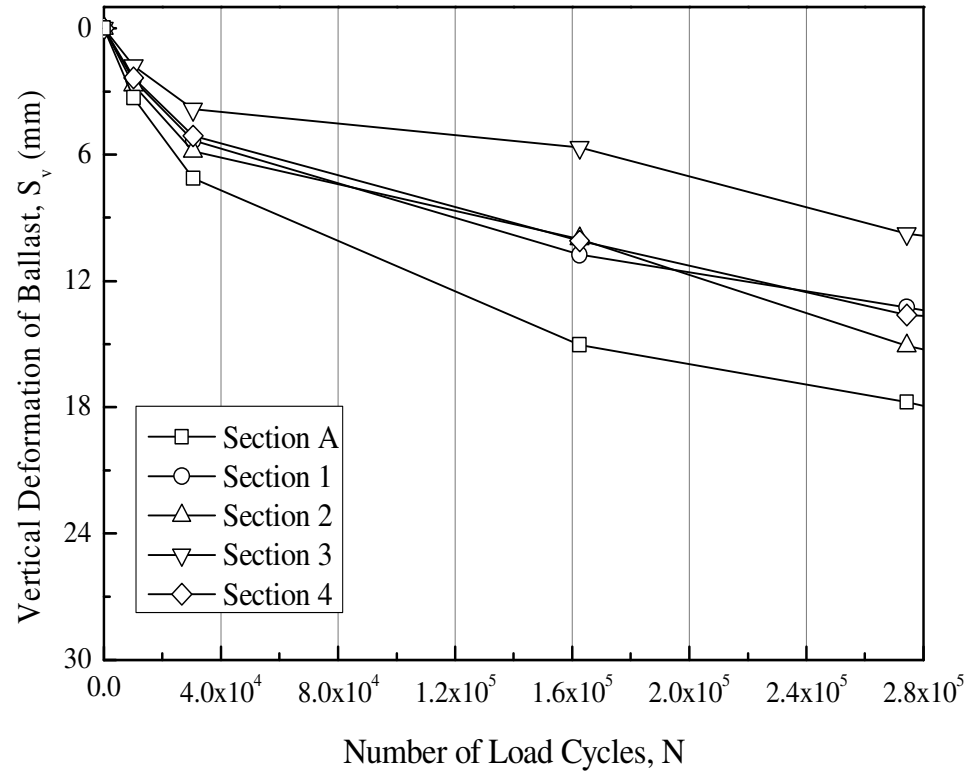

(b)

Figure 5. (a) Location of track sections constructed in Singleton; (b) Vertical deformation of ballast layer measured at various locations (modified after Indraratna et al.[22]) 


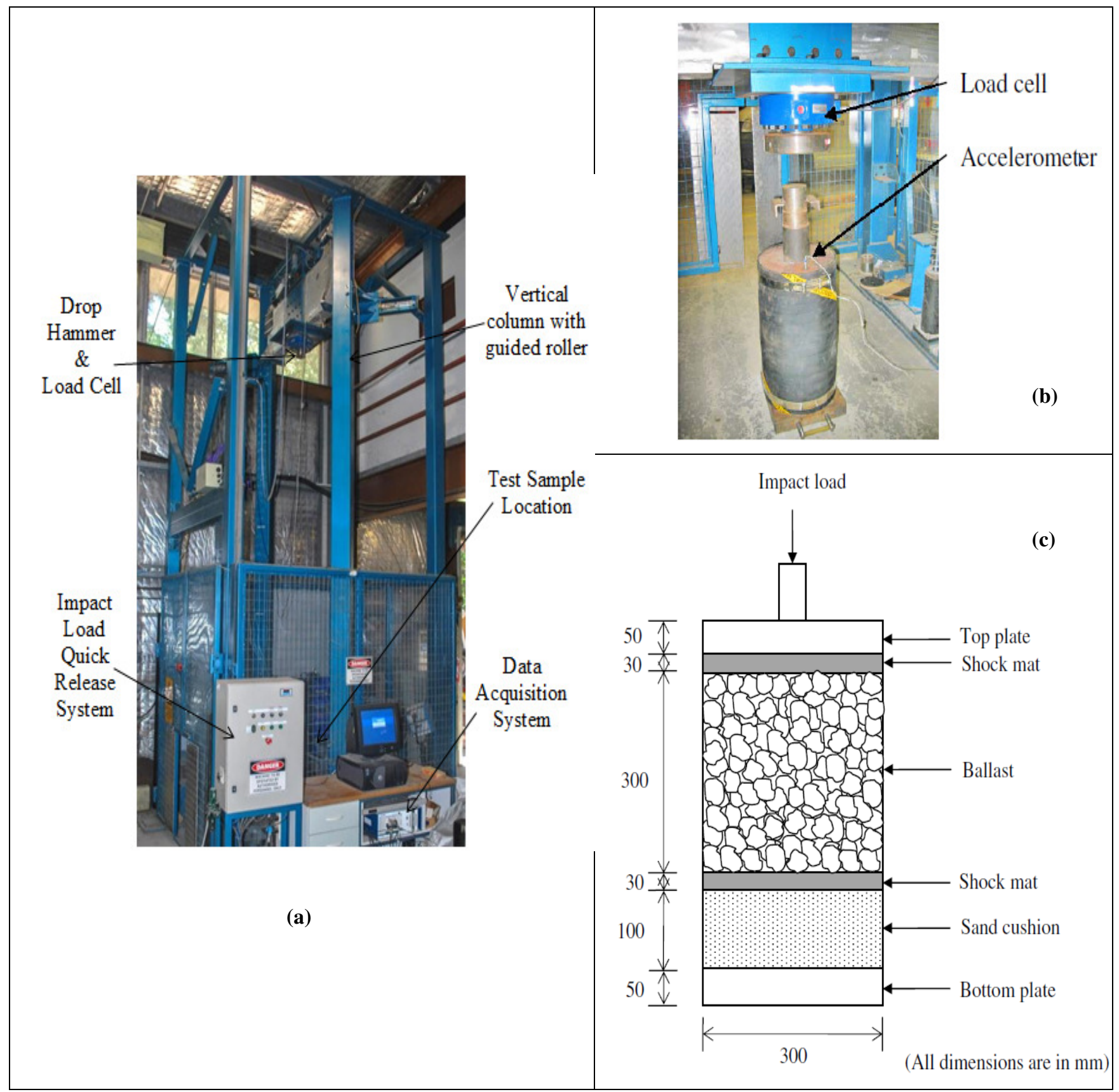

Figure 6. Impact testing system apparatus: (a) Perspective view of the equipment; (b) ballast specimen; (c) Schematic diagram of a typical test specimen 
(a)

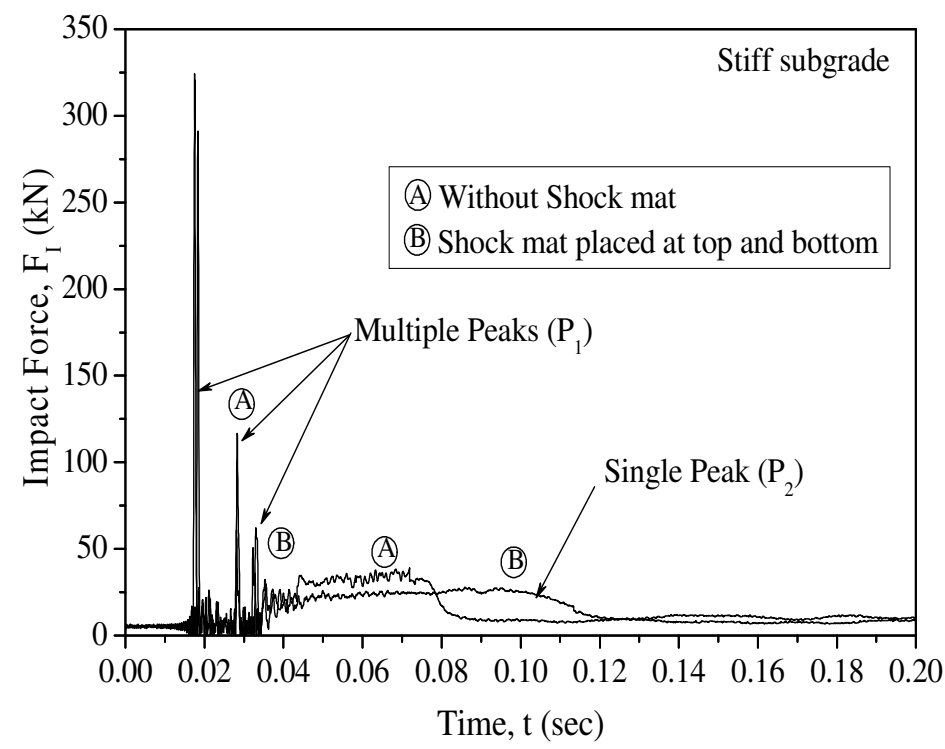

(b)

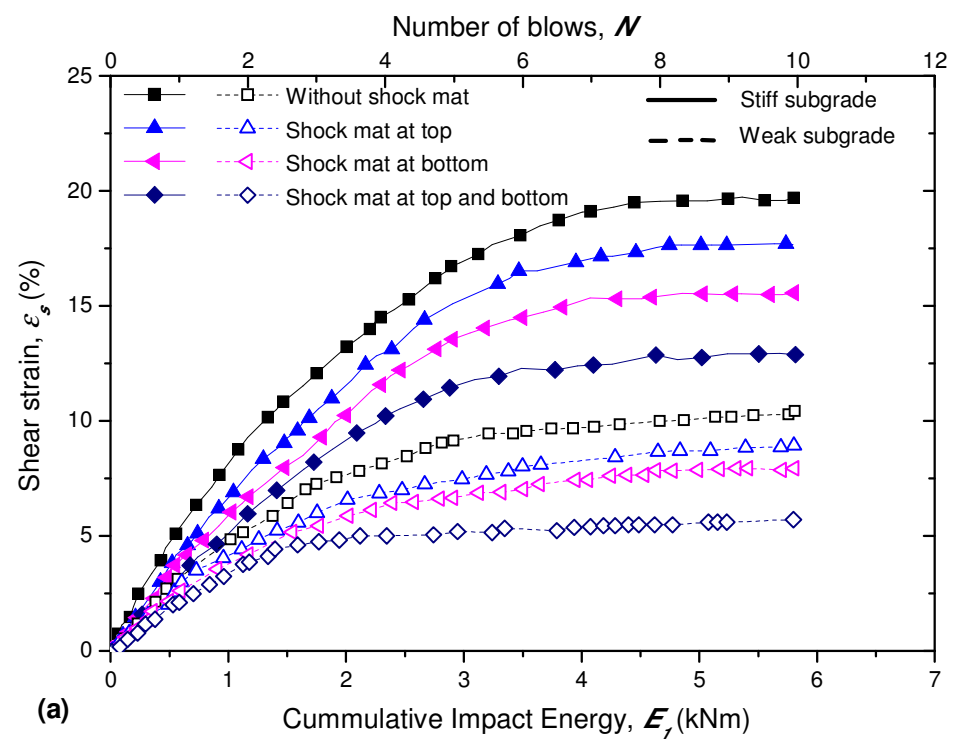

Figure 7. (a) Impact force responses measured in laboratory; (b) Measured shear strain behaviour of ballast with and without shock mat (modified after Nimbalkar et al.[33]) 

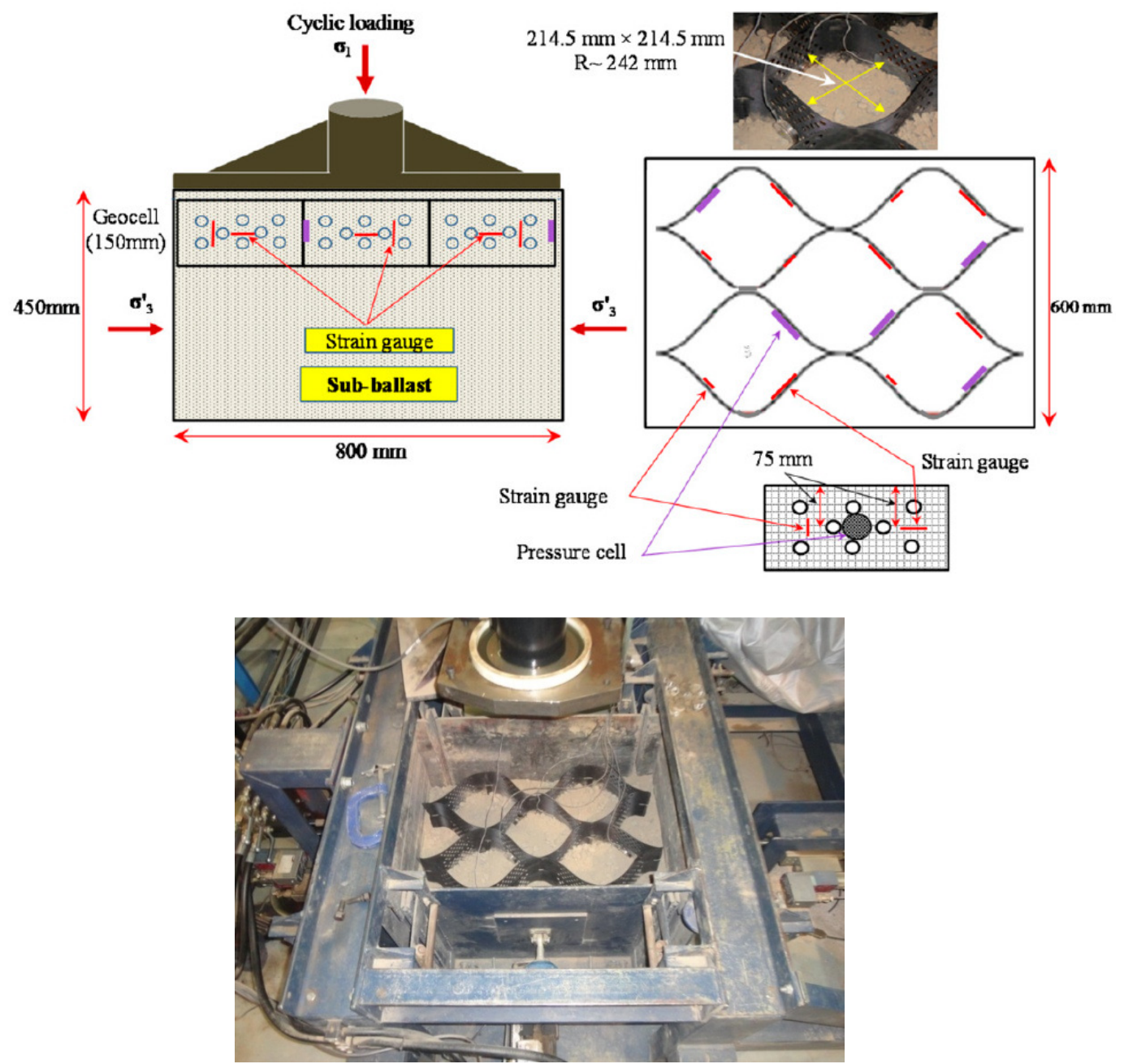

Figure 8. Laboratory setup for testing of geocell-reinforced subballast (modified after Indraratna et al. [18]) 


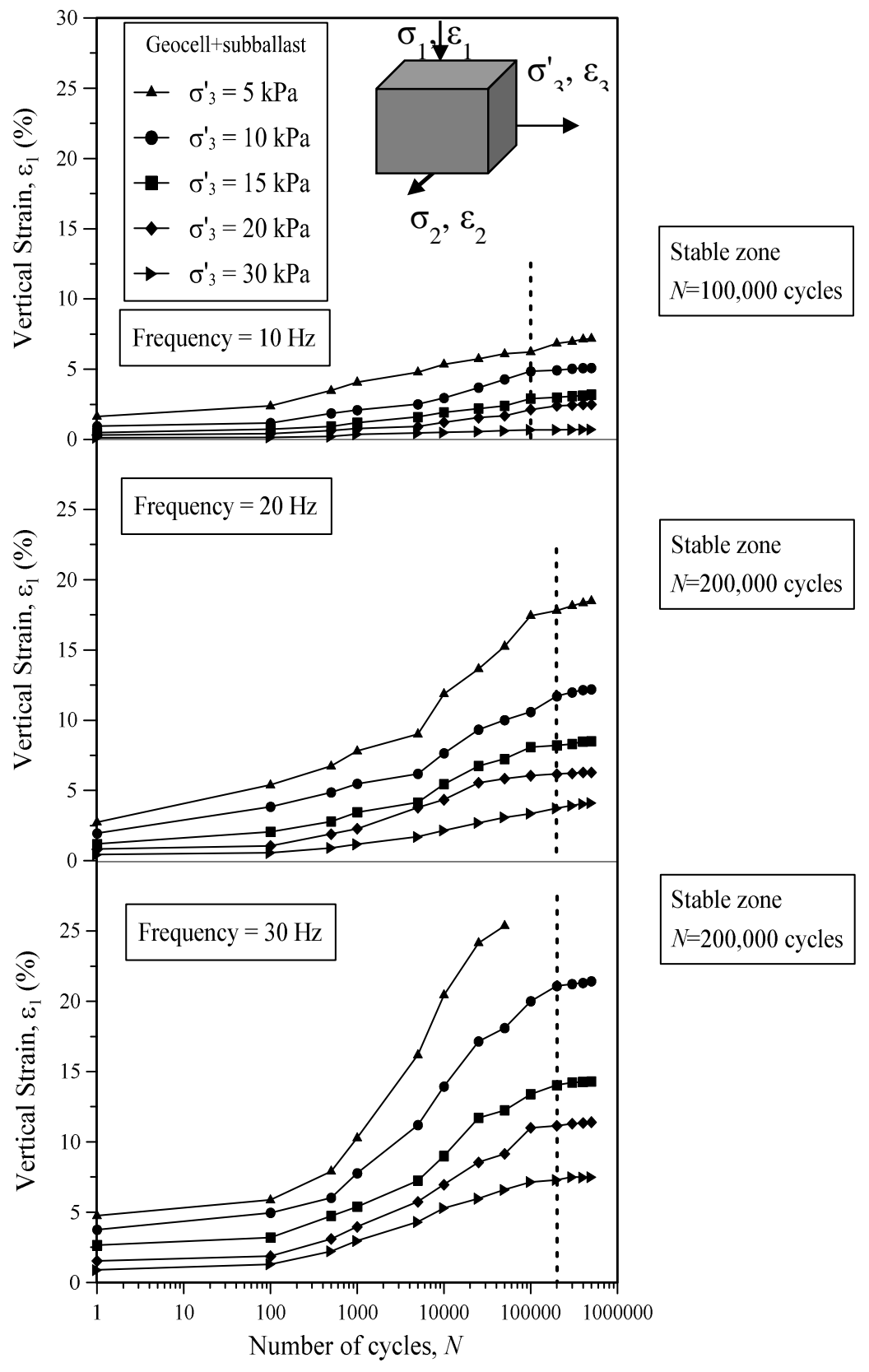

Figure 9. Variations of vertical strain against number of cycles for geocell-reinforced subballast at various frequencies and confining pressures (modified after Indraratna et al.[18]) 
Deviator stress, q $(\mathrm{kPa})$

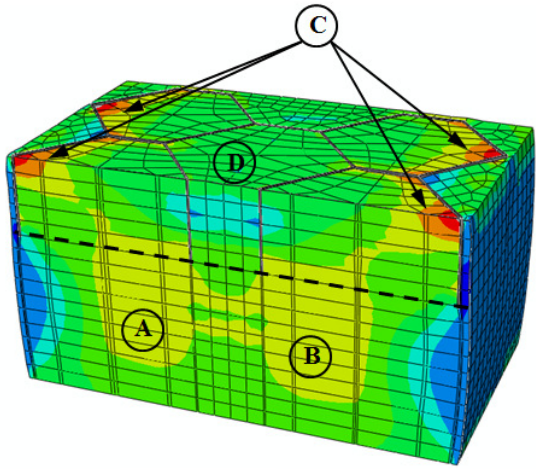

(a)
Vertical settlement, $S_{V}(\mathrm{~m})$
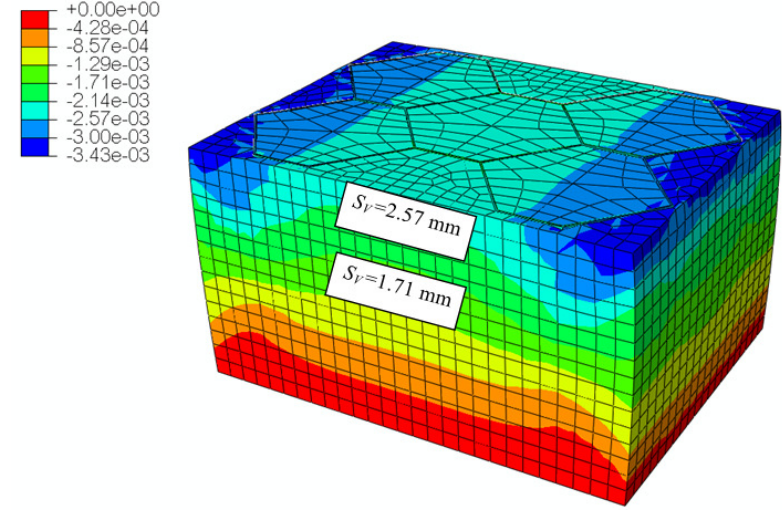

(b)

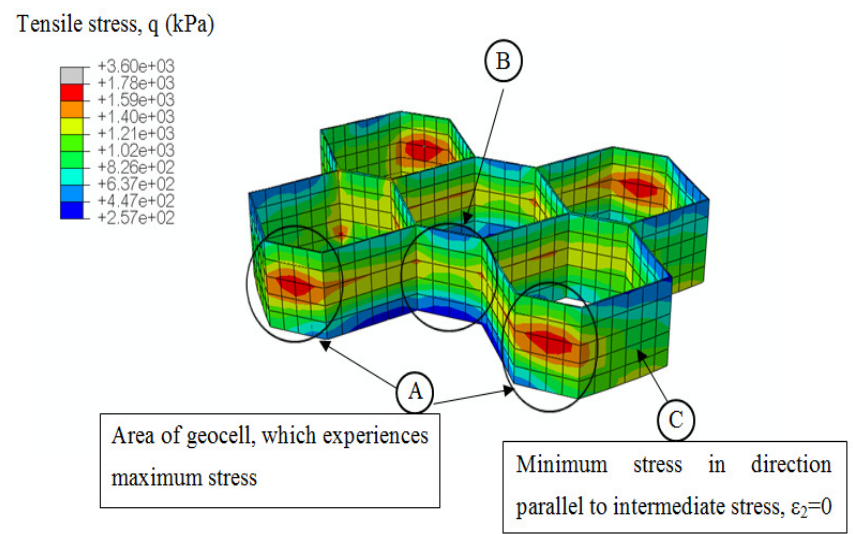

(c)

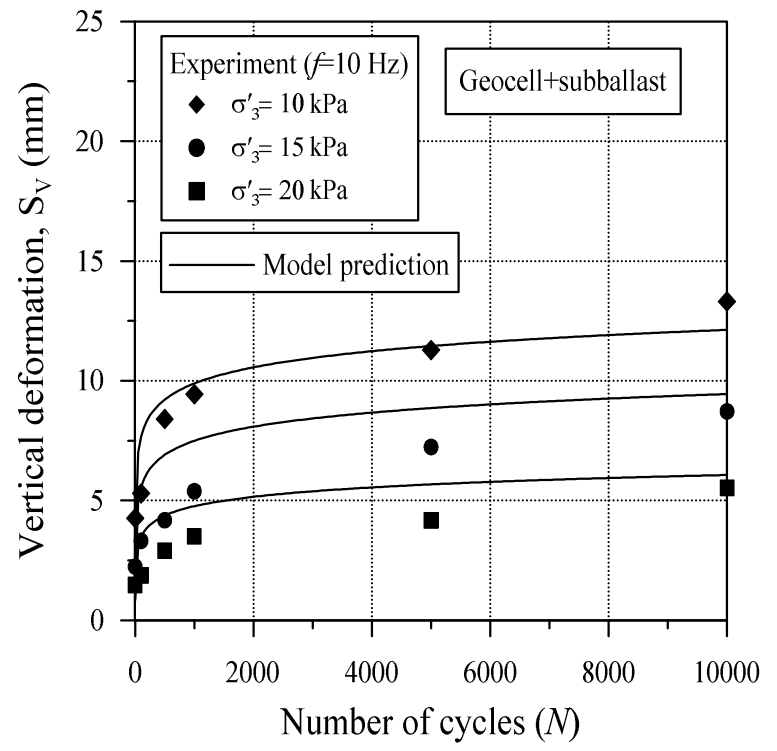

(d)

Figure 10. FEM analysis for geocell-reinforced subballast: (a) deviatoric stress contour; (b) vertical settlement contour; (c) tensile stress developed in a geocell; and (d) predicted subballast settlements versus measured data (modified after Biabani et al.[17]). 


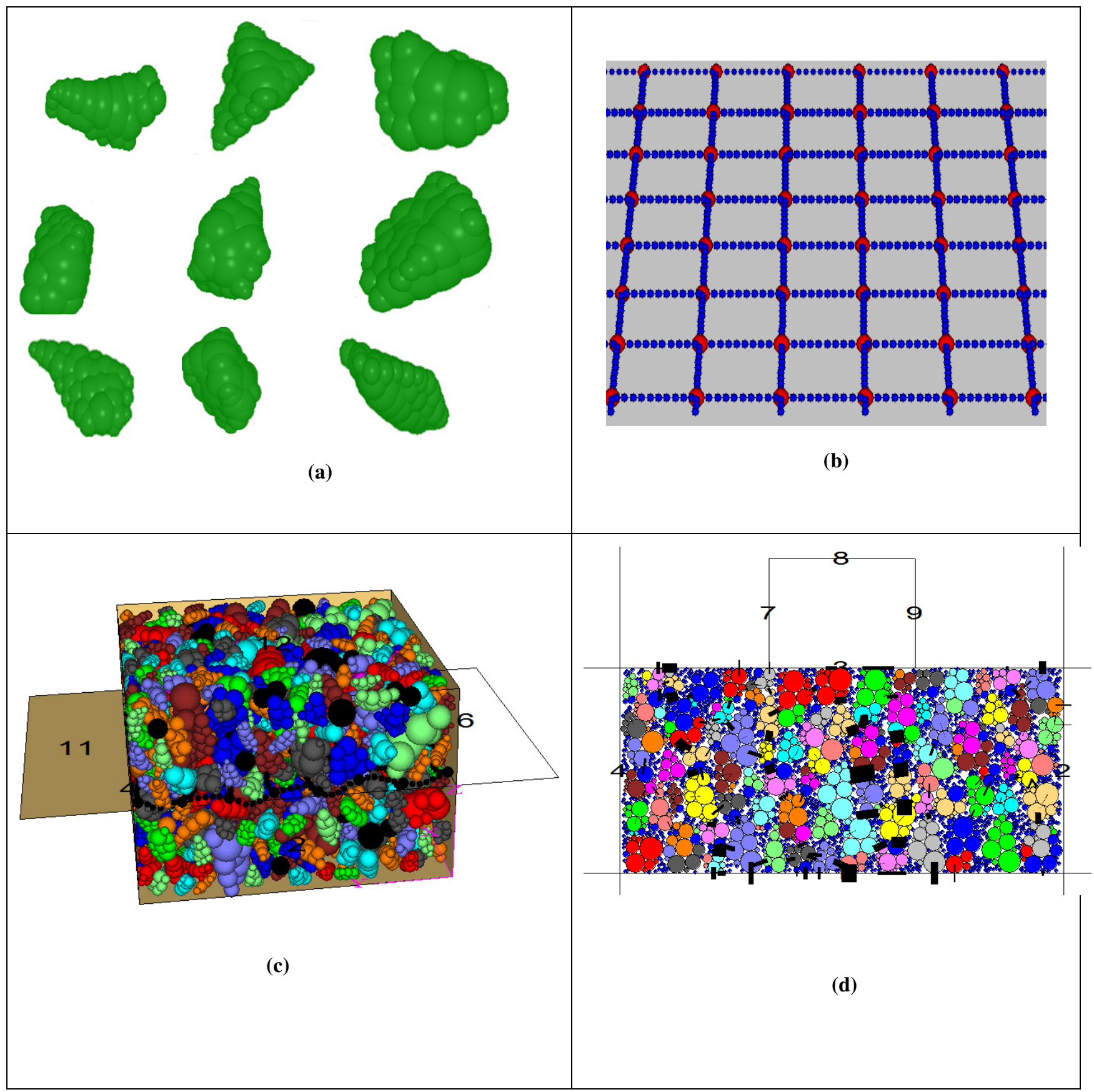

Figure 11. Discrete element modelling of geogrid-reinforced ballast: (a) modelled ballast grains; (b) modelled geogrid; (c) large-scale direct shear box; and (c) track process simulation apparatus 


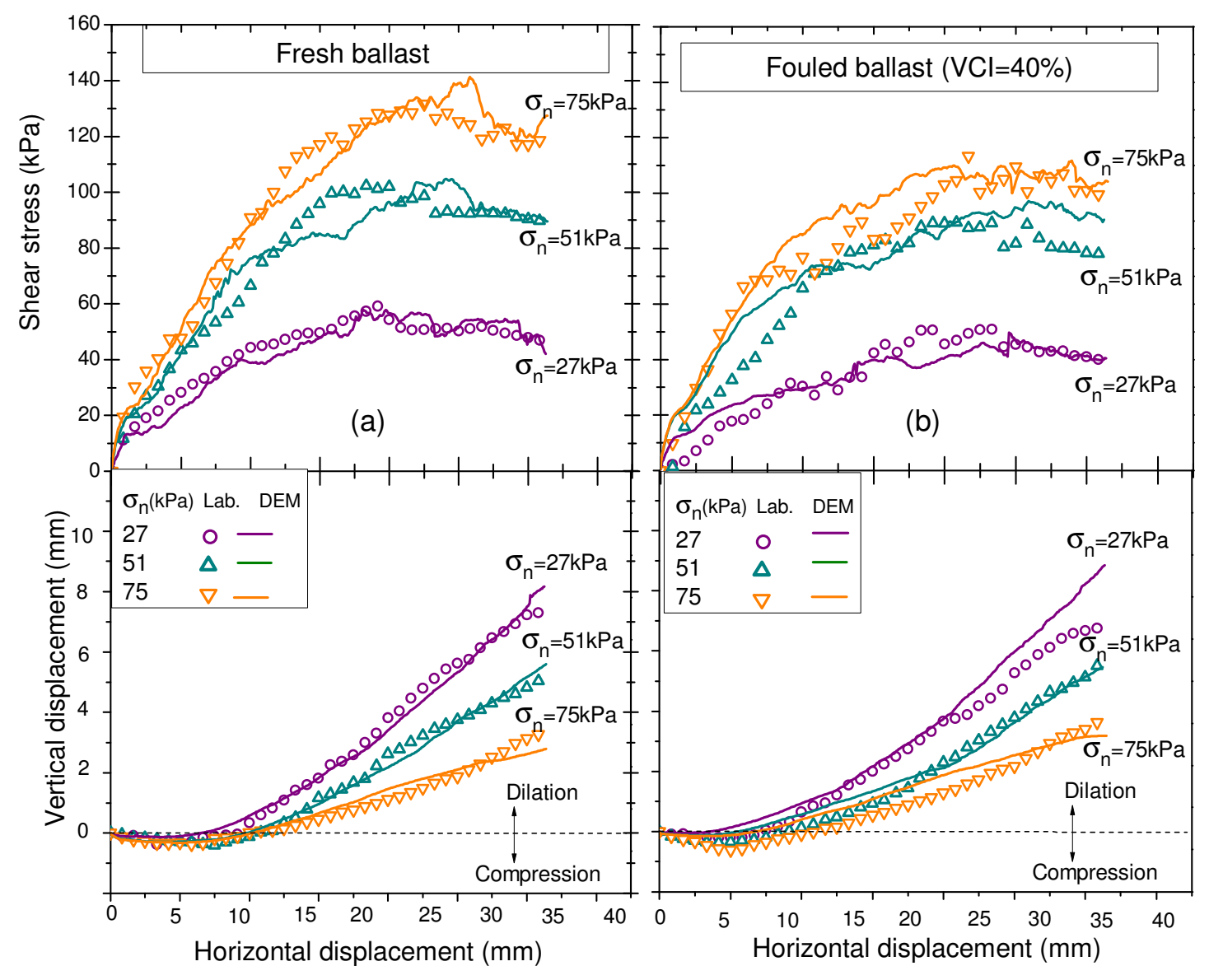

Figure 12. Comparisons of shear stress-strain behaviour of geogrid-reinforced ballast between laboratory test and DEM simulation: (a) fresh ballast; and (b) fouled ballast (modified after Ngo et al. [44]) 


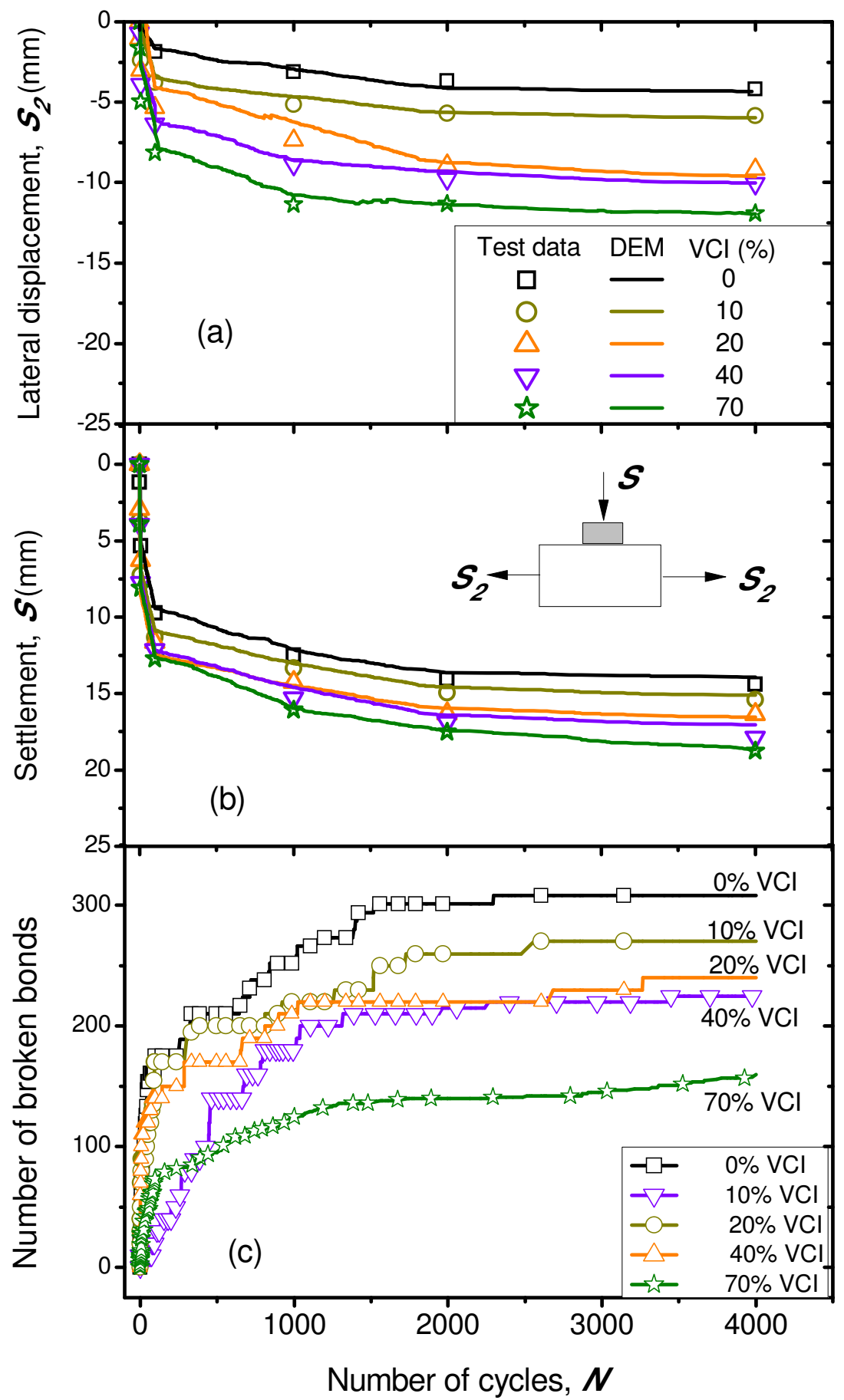

Figure 13. Comparisons of lateral and vertical deformation between laboratory data and DEM simulations: (a) lateral displacement; (b) settlement; (c) number of broken bonds (modified after Indraratna et al.[11]) 


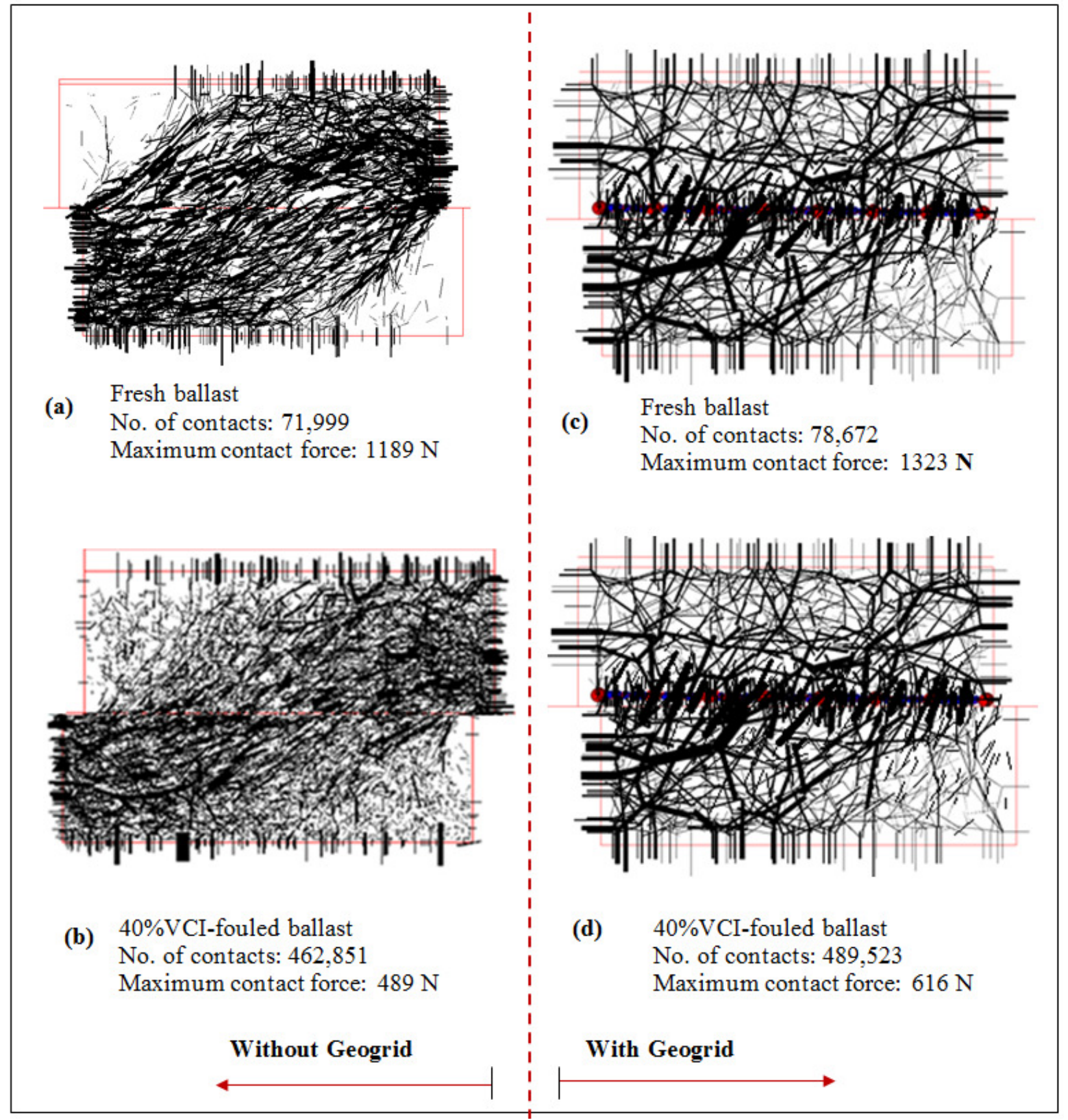

Figure 14. Distributions of contact forces: (a) unreinforced-fresh ballast; (b) 40\%VCI-unreinfoced 3 ballast; (c) geogrid-reinforced fresh ballast; (d) geogrid reinforced fouled ballast (modified after Ngo et al.[44]) 